October 2004 • NREL/TP-500-36824

\title{
The Alaska Village Electric Load Calculator
}

M. Devine

University of Massachusetts Amherst

E.I. Baring-Gould

National Renewable Energy Laboratory

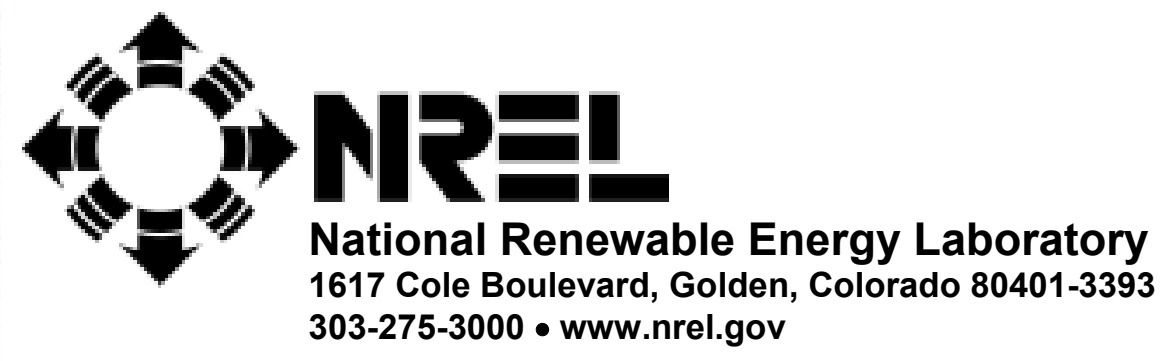

Operated for the U.S. Department of Energy

Office of Energy Efficiency and Renewable Energy

by Midwest Research Institute • Battelle

Contract No. DE-AC36-99-G010337 


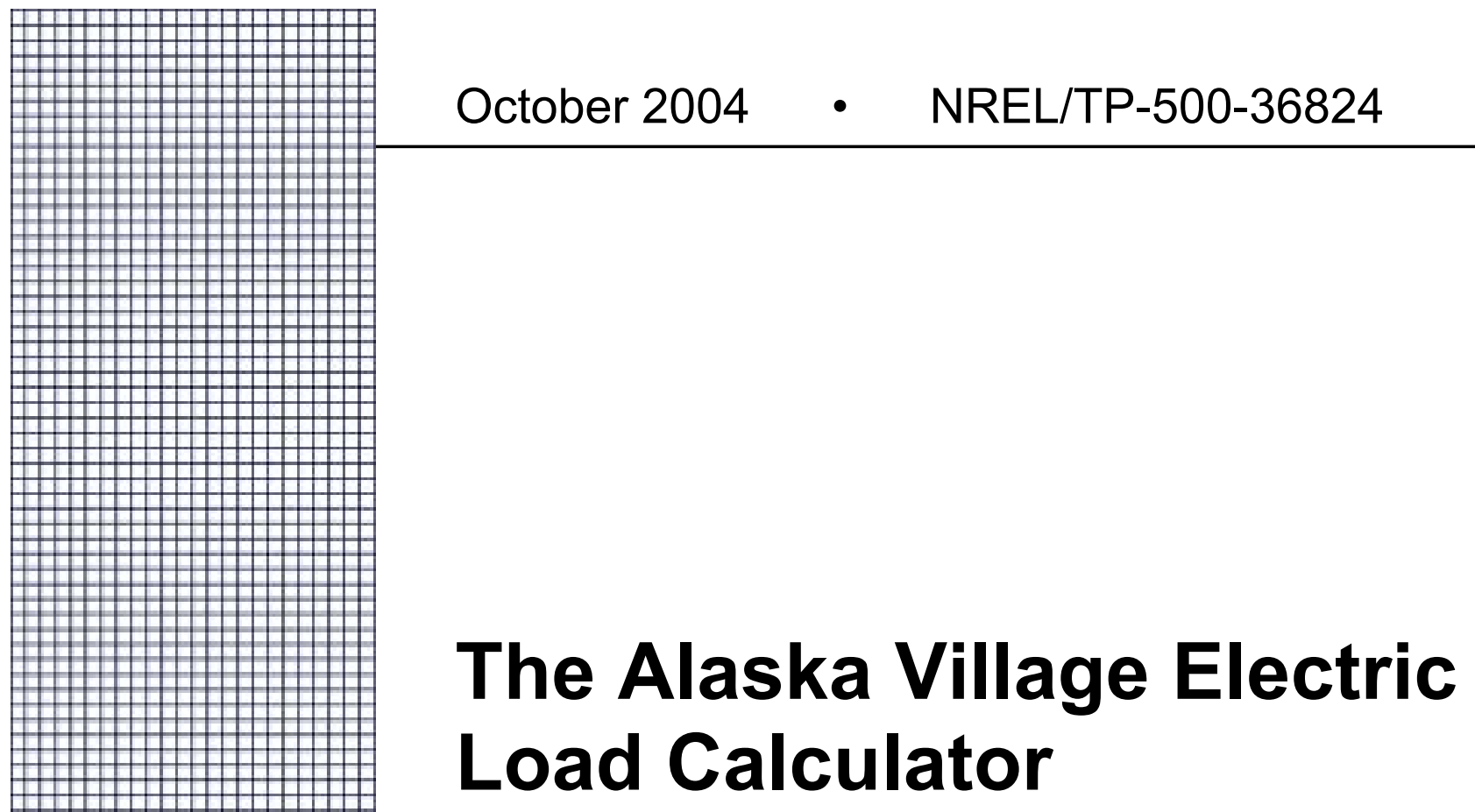

M. Devine

University of Massachusetts Amherst

E.I. Baring-Gould

National Renewable Energy Laboratory

Prepared under Task No. WER4.6002

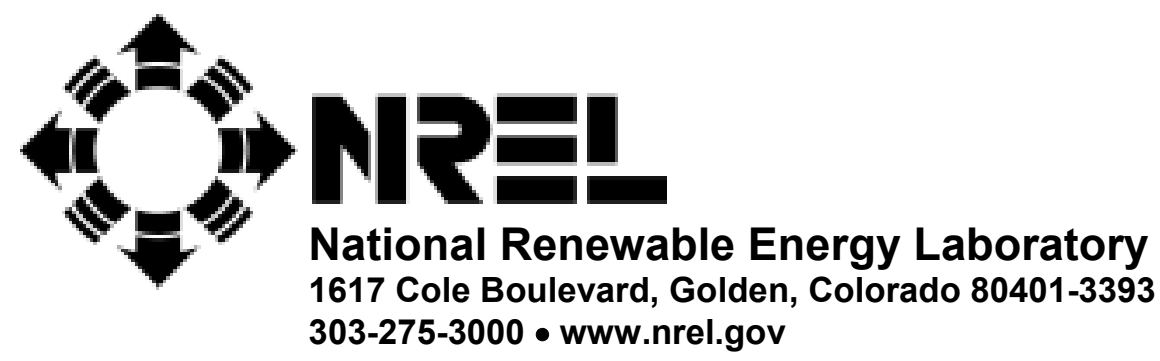

Operated for the U.S. Department of Energy

Office of Energy Efficiency and Renewable Energy

by Midwest Research Institute • Battelle

Contract No. DE-AC36-99-G010337 


\section{NOTICE}

This report was prepared as an account of work sponsored by an agency of the United States government. Neither the United States government nor any agency thereof, nor any of their employees, makes any warranty, express or implied, or assumes any legal liability or responsibility for the accuracy, completeness, or usefulness of any information, apparatus, product, or process disclosed, or represents that its use would not infringe privately owned rights. Reference herein to any specific commercial product, process, or service by trade name, trademark, manufacturer, or otherwise does not necessarily constitute or imply its endorsement, recommendation, or favoring by the United States government or any agency thereof. The views and opinions of authors expressed herein do not necessarily state or reflect those of the United States government or any agency thereof.

Available electronically at http://www.osti.gov/bridge

Available for a processing fee to U.S. Department of Energy and its contractors, in paper, from:

U.S. Department of Energy

Office of Scientific and Technical Information

P.O. Box 62

Oak Ridge, TN 37831-0062

phone: 865.576.8401

fax: 865.576.5728

email: mailto:reports@adonis.osti.gov

Available for sale to the public, in paper, from:

U.S. Department of Commerce

National Technical Information Service

5285 Port Royal Road

Springfield, VA 22161

phone: 800.553 .6847

fax: 703.605.6900

email: orders@ntis.fedworld.gov

online ordering: http://www.ntis.gov/ordering.htm 


\section{TABLE OF CONTENTS}

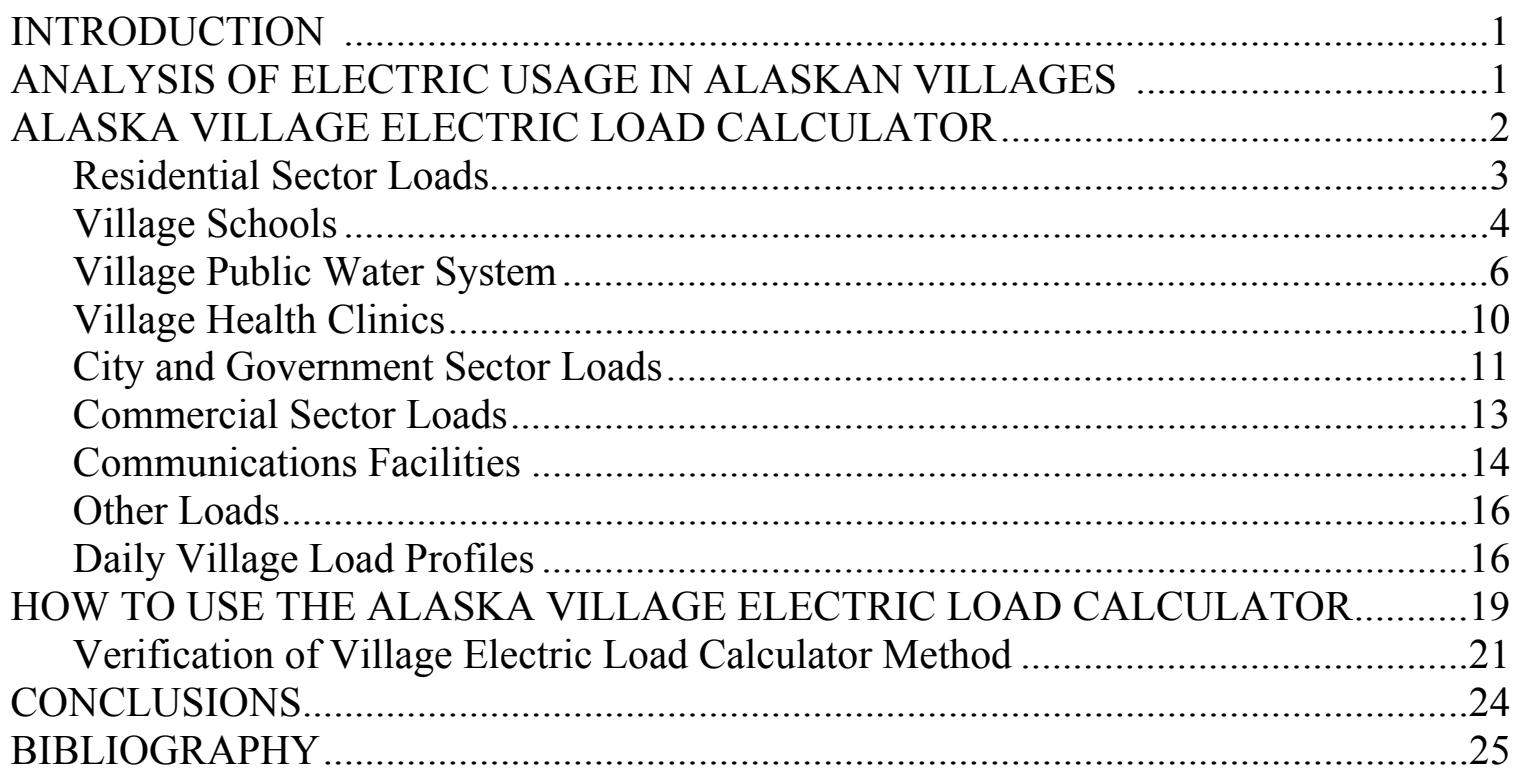

\section{LIST OF FIGURES}

Figure 1. Relative load consumption by facility type in a typical village ..........................1

Figure 2. Annual change in village electric usage by sector..........................................2

Figure 3. Energy consumption of residential sector in sample villages .............................. 3

Figure 4. Seasonal electric consumption of residential sector ............................................

Figure 5. Energy consumption of sample village schools ................................................

Figure 6. Energy consumption of village K-12 school ..................................................6

Figure 7. Energy consumption of sample Level I piped water systems. .............................

Figure 8. Energy consumption of Level I public water systems........................................8

Figure 9. Energy consumption of Level II public water systems .......................................

Figure 10. Energy consumption of Level II public water systems ....................................9

Figure 11. Energy consumption of sample village health clinics .....................................10

Figure 12. Electric consumption of village health clinics................................................11

Figure 13. Energy consumption of sample city/government buildings ..............................11

Figure 14. Energy consumption of city buildings.........................................................12

Figure 15. Energy consumption of sample commercial facilities......................................13

Figure 16. Energy consumption of commercial buildings ................................................14

Figure 17. Energy consumption of sample communications facilities ...............................15

Figure 18. Energy consumption of communications sector loads ....................................16

Figure 19. Daily load profiles for Selawik, Alaska .......................................................17

Figure 20. January daily load profile for sample villages................................................18

Figure 21. July daily load profiles for sample villages....................................................18 
Figure 22. Example results from the Alaska Village Electric Load Calculator.................20

Figure 23. Estimated hourly electric load in Brevig Mission ......................................20

Figure 24. Brevig Mission 2003 estimate versus actual consumption ...........................21

Figure 25. Village Electric Load Calculator results for the village of Toksook Bay ........22

Figure 26. Village Electric Load Calculator results for the village of Mekoryuk .............22

Figure 27. Village Electric Load Calculator results for the village of Kiana ...................23

Figure 28. Load calculator model verification - village of Selawik..............................24

\section{LIST OF TABLES}

Table 1. Electric Consumption of Residential Sector ...............................................

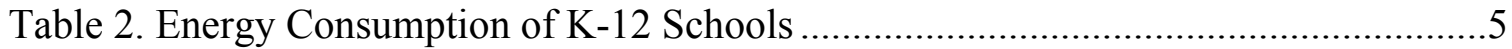

Table 3. Energy Consumption of Level I Public Water Systems ....................................... 7

Table 4. Energy Consumption of Level II Public Water Systems .....................................9

Table 5. Electric Consumption for Village Health Clinics .............................................10

Table 6. Electric Consumption of City and Government Buildings ................................12

Table 7. Electric Consumption of Commercial Facilities...........................................13

Table 8. Energy Consumption of Communications Sector ........................................... 15

Table 9. Electric Load Calculator Inputs for Brevig Mission.........................................19

Table 10. Village Electric Load Calculator Inputs for the Village of Toksook Bay .........21

Table 11. Village Electric Load Calculator Inputs for the Village of Mekoryuk ..............22

Table 12. Village Electric Load Calculator Inputs for the Village of Kiana .....................23

Table 13. Load Calculator Inputs for Selawik ........................................................24 


\section{INTRODUCTION}

About a quarter of Alaska's population of 640,000 live in isolated villages scattered across the state. More than 118 independent utilities provide electricity to Alaska's geographically, economically, and culturally diverse range of communities (Alaska Energy Authority, 2003). Alaska's rugged terrain and lack of roadway systems make supplying its rural communities with electricity a challenge. Most of these communities are powered by diesel minigrids of up to 3 megawatts (MW) in capacity. As the electric demand in these villages continues to grow, many of the power plant complexes are in need of major upgrades. Due to the high operation and maintenance costs of diesel systems, as well as the environmental hazards associated with diesel generators, some villages are investigating the possibility of integrating wind energy into the existing diesel power system.

As part of designing a village electric power system, the present and future electric loads must be defined, including both seasonal and daily usage patterns. However, in many cases, detailed electric load information is not readily available. NREL developed the Alaska Village Electric Load Calculator to help estimate the electricity requirements in a village given basic information about the types of facilities located within the community. The purpose of this report is to explain how the load calculator was developed and to provide instructions on its use so that organizations can then use this model to calculate expected electrical energy usage.

The Alaska Village Electric Cooperative (AVEC), a nonprofit rural electric utility based in Anchorage, operates about 50 power stations serving remote villages ranging in size from 100 to 1,100 residents. Much of the data used in this analysis was provided by AVEC and this paper will use those villages as examples. However, the Alaska Village Electric Load Calculator can also be applied to non-AVEC villages in Alaska and other similar remote arctic communities.

\section{ANALYSIS OF ELECTRIC USAGE IN ALASKAN VILLAGES}

To begin the electric load analysis, the electric consumption from a number of communities was broken down into its primary components: residential sector, schools, commercial sector, public water system, city/ government buildings, communications facilities, and the health clinic.

Figure 1 shows the relative size of each of those sectors from one of the villages.

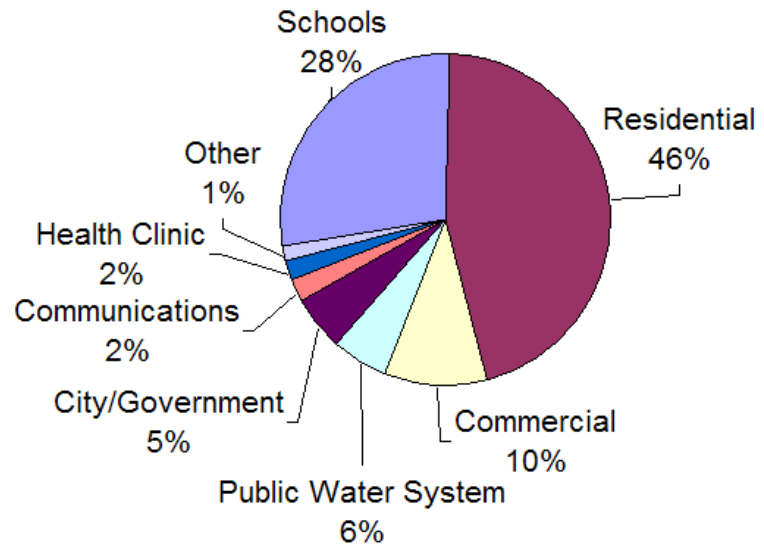

Figure 1. Relative load consumption by facility type in a typical village. 
The residential sector is the largest consumer group, followed by the school. The commercial sector makes up about $10 \%$ of the village electric consumption and typically includes a general store, hardware store, and a number of restaurants. Figure 2 shows the annual growth in energy demand from each sector that makes up AVEC's customer base. These data are valuable as they provide insight to the primary load growth areas within a community.

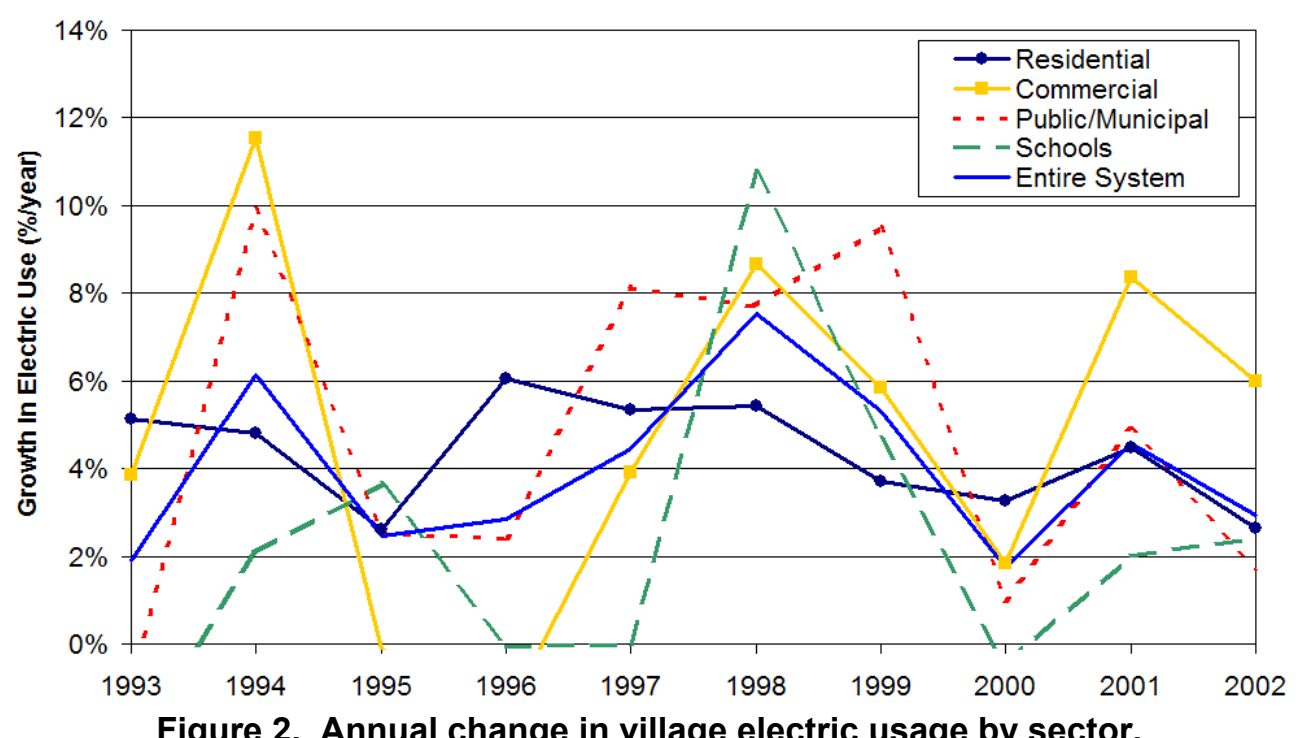

The residential sector, generally the largest load sector, increases at a gradual rate of about $4 \%$ per year through general consumption increases and new housing connections. The expansion of municipal services, schools, and commercial applications provide large and highly variable load increases to a community. Due to funding processes of facility expansion, both municipal and school expansions are widely known and can be planned into power systems needs accordingly, thus limiting surprise impacts. Expansion of commercial loads is not easy to plan for and could quickly change the energy needs of a community. However, commercial loads generally make up less than $15 \%$ of a community's total load, and thus large increases will have a limited impact compared to the residential and municipal loads that make up the remaining $85 \%$ of a community's electricity needs.

\section{ALASKA VILLAGE ELECTRIC LOAD CALCULATOR}

The electric use patterns of each consumer sector was investigated in detail based on the electric utility records. The consumption patterns were then incorporated into the Alaska Village Electric Load Calculator, which adds up the various load profiles within a village using a building block approach. This report describes the method used to create the building blocks for each consumer sector and the procedure for using the calculator to determine hourly electric load data.

Throughout this analysis the energy consumption of certain loads has been normalized by the population within each community. This allows easy comparisons between communities of various sizes and also acts as a reasonable baseline for community level services and energy use. Other normalization techniques were investigated; however, normalization by total community population provided the most promising results. Some loads, such as the communication sector, which are not dependent on the size of a community have not been normalized. 


\section{Residential Sector Loads}

The residential sector generally makes up about $45 \%$ of a village's total electric consumption. Electric loads found in typical homes include lighting, a color TV, electric stove, refrigerator, forced air fan, and a clock radio. Homes with piped water may have electric heat tape to prevent water mains from freezing. More modern homes might have a computer, washer and dryer, satellite dish, microwave, and additional lights and television sets (Vallee, 2003). The more modern homes will use as much as 1,000 kilowatt-hours $(\mathrm{kWh})$ or more a month; however, the majority of village homes use 200 to $400 \mathrm{kWh}$ per month.

It is difficult to characterize the monthly electric consumption of the residential sector because billing information for individual consumers is not readily available. However, the energy consumption of the residential sector in six different villages was obtained for the three months of November 2002, April 2003, and July 2003. The results are shown in Figure 3. The data points for the remaining nine months were estimated based on the seasonal shape of the total village load profile. The resulting average seasonal electric load profile for the residential sector is also shown in Figure 3.

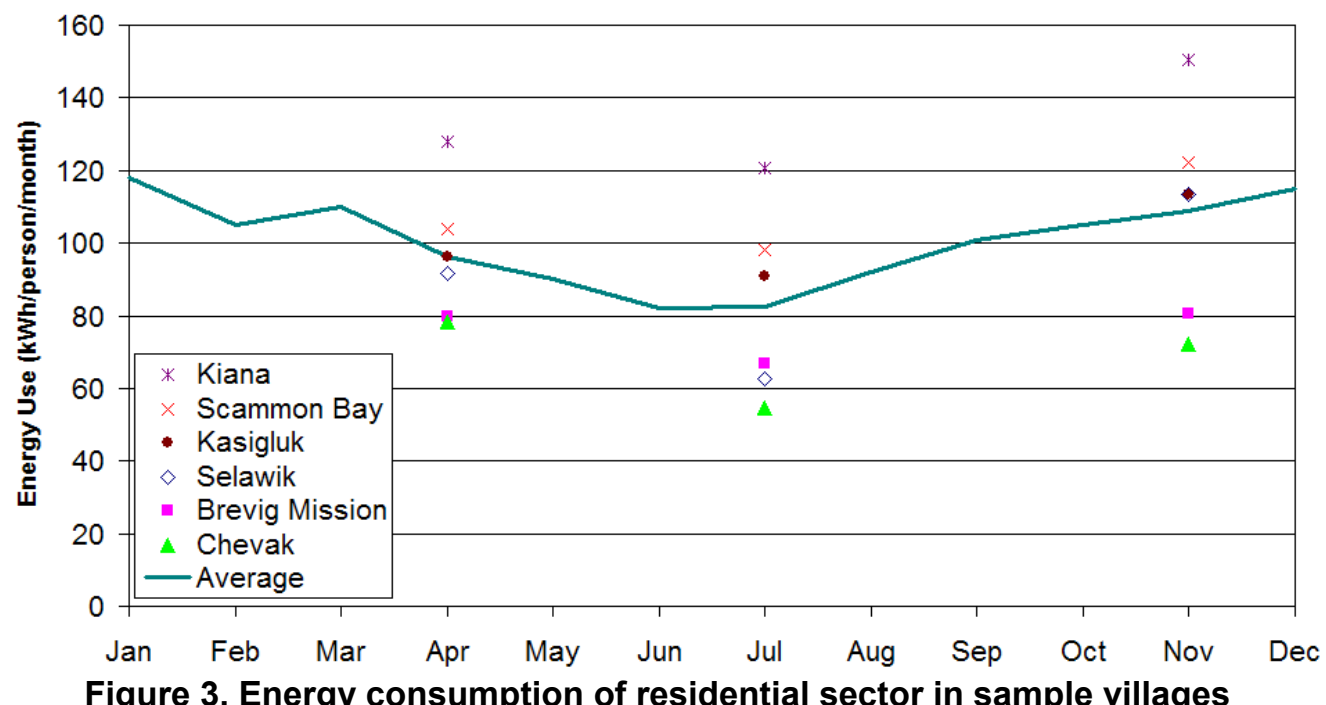

To determine why some villages have a higher per capita residential electric consumption than other villages, characteristics relating to the residential sector in each village were gathered. Statistics from the 2000 U.S. Census, such as people per household, unemployment rate, percent of population below poverty, and per capita income, were chosen because they were readily available and could easily be compared with other villages (Department of Community and Economic Development, 2003). Comparing the community statistics to the per capita energy consumption of each village, it seemed that the median household income most closely correlated to the level of energy use. This assumption coincides with reports concluding that economic growth is directly related to an increase in household energy consumption. As the level of household income increases, residents often purchase larger housing units and additional appliances, leading to increased energy consumption (Energy Information Administration, 2004). 
The average median household income for remote villages in AVEC's service territory is about $\$ 31,500$. Based on this median, Table 1 divides the residential sector into three income categories.

Table 1. Electric Consumption of Residential Sector

\begin{tabular}{|r|c|c|c|}
\hline Category: & Low & Medium & High \\
\hline $\begin{array}{r}\text { Median Household } \\
\text { Income: }\end{array}$ & Less than $\$ 25,000$ & $\$ 25,000$ to $\$ 35,000$ & $\begin{array}{c}\text { More than } \\
\$ 35,000\end{array}$ \\
\hline Monthly & & & \\
Consumption & $(\mathrm{kWh} /$ person/mo. $)$ & $(\mathrm{kWh} /$ person/mo. $)$ & $(\mathrm{kWh} /$ person/mo. $)$ \\
Jan & 89 & 118 & 159 \\
Feb & 84 & 105 & 142 \\
Mar & 88 & 110 & 146 \\
Apr & 78 & 96 & 128 \\
May & 65 & 90 & 123 \\
June & 58 & 84 & 121 \\
July & 55 & 82 & 121 \\
Aug & 62 & 101 & 129 \\
Sept & 68 & 105 & 141 \\
Oct & 70 & 109 & 147 \\
Nov & 72 & 115 & 150 \\
Dec & 81 & & \\
\hline
\end{tabular}

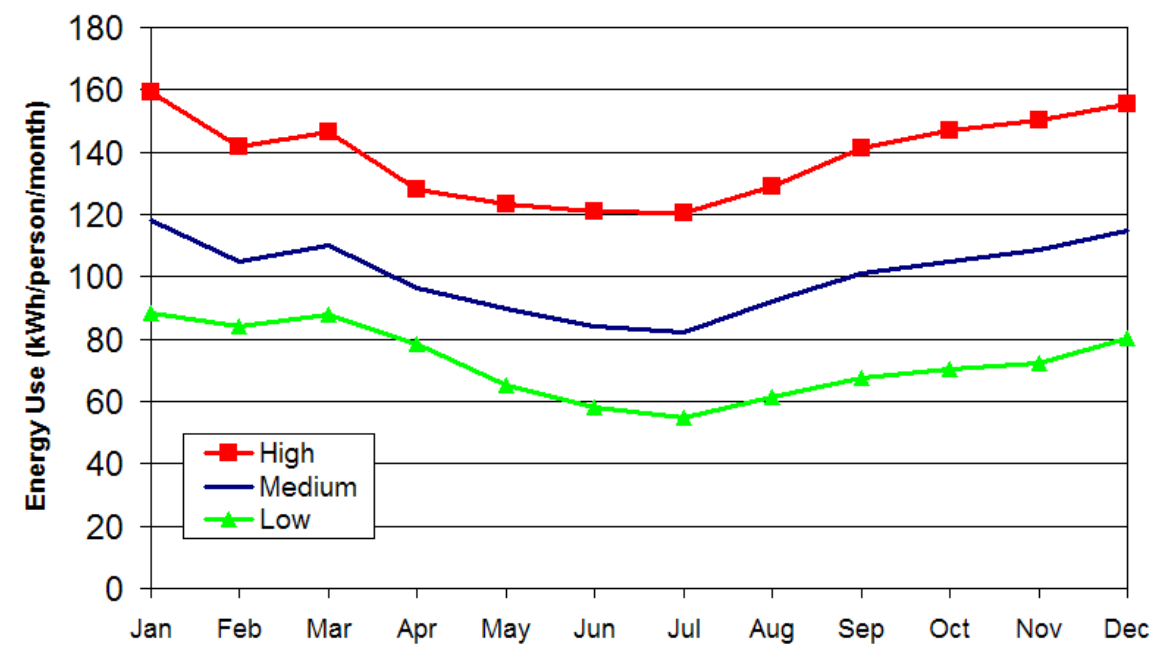

Figure 4. Seasonal electric consumption of residential sector.

The values listed in Table 1 and shown in Figure 4 serve as the building block for the residential sector to be included in the Alaska Village Electric Load Calculator.

\section{Village Schools}

As the largest individual consumer of electricity in a village, the local school has a great impact on the total village electric load profile. The electric consumption of eight village schools from 1998 through June 2003 was observed to have a similar seasonal load pattern. An average year of per capita electric consumption of each school is shown in Figure 5. 


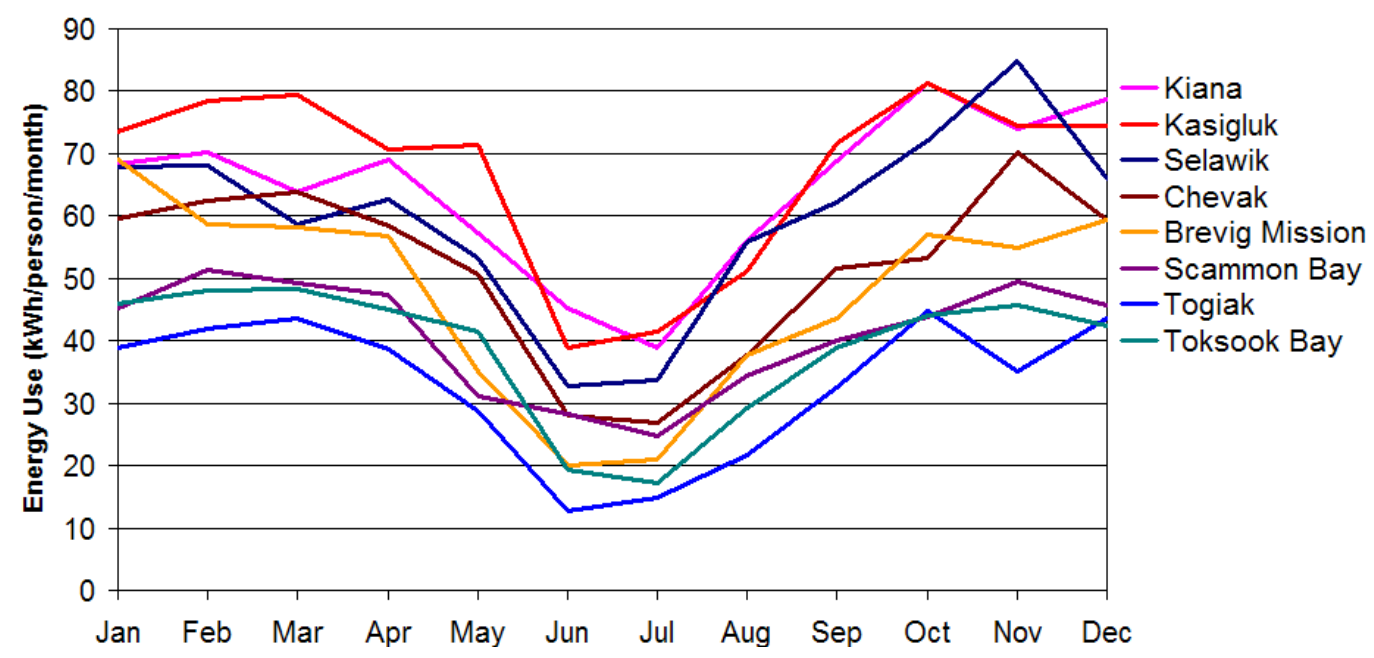

Figure 5. Energy consumption of sample village schools.

The variation in electric consumption between schools is due to the type of electrical equipment available in the building as well as the hours of operation. Kasigluk has two school buildings, a P-12 and a K-12. Combining their electric usage, they use more electricity per capita than the other villages. The Brevig Mission school is in the mid range of electric consumption per capita. Major loads within the school include air handling units, an electric dryer, water pumps for the hot water radiator system, and kitchen appliances. For safety reasons, all ovens in the cafeteria use electricity rather than propane. Heat is provided by oil-fired furnaces. The building, particularly the gym and library, is used in the evenings and weekends for after school programs and community meetings but is used very little in the summer (Davis, 2003). The Scammon Bay, Togiak, and Toksook Bay schools are all located in maritime climates with limited electric heating loads. To distinguish among the range of electric use between schools, these facilities are divided into three categories, as described in Table 2.

Table 2. Energy Consumption of K-12 Schools

\begin{tabular}{|c|c|c|c|}
\hline Category: & Low & Medium & High \\
\hline Characteristics: & $\begin{array}{l}\text { Located in southern/ } \\
\text { maritime climate } \\
\text { region, uses propane or } \\
\text { gas for heating and } \\
\text { cooking. }\end{array}$ & $\begin{array}{l}\text { Average school with air } \\
\text { handling units and } \\
\text { some electrical } \\
\text { appliances. }\end{array}$ & $\begin{array}{l}\text { Located in the arctic climate } \\
\text { region, has its own septic } \\
\text { system, uses electric heaters } \\
\text { and stoves, or more than one } \\
\text { building. }\end{array}$ \\
\hline Monthly & & & \\
\hline Consumption & (kWh/person/month) & (kWh/person/month) & (kWh/person/month) \\
\hline Jan & 38.8 & 58.5 & 73.4 \\
\hline Feb & 42.0 & 59.9 & 78.6 \\
\hline Mar & 43.6 & 58.2 & 79.4 \\
\hline Apr & 38.6 & 56.1 & 70.8 \\
\hline May & 28.7 & 46.1 & 71.3 \\
\hline June & 12.7 & 28.2 & 45.3 \\
\hline July & 14.8 & 27.4 & 41.5 \\
\hline Aug & 21.6 & 40.5 & 56.2 \\
\hline Sept & 32.5 & 51.2 & 71.5 \\
\hline Oct & 43.9 & 59.7 & 81.4 \\
\hline Nov & 42.0 & 61.1 & 84.8 \\
\hline Dec & 42.3 & 58.7 & 78.8 \\
\hline
\end{tabular}


The monthly energy consumption of the different categories of schools is listed in Table 2 and shown in Figure 6. These values serve as the building block for the school sector in the Alaska Village Electric Load Calculator.

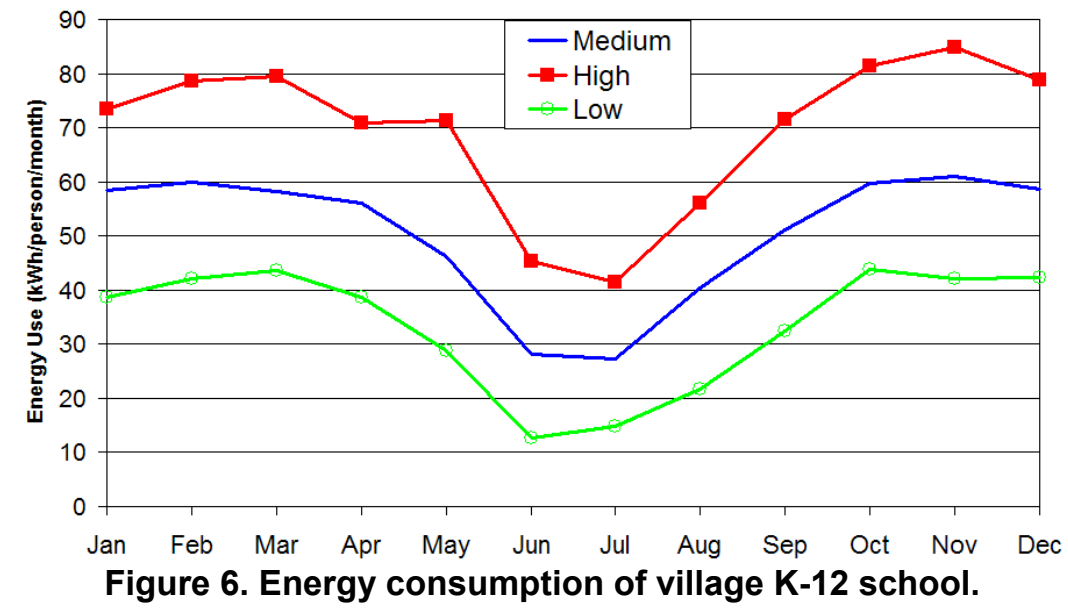

\section{Village Public Water System}

Village public water systems include any facilities that supply water to a community and that dispose of wastewater. There are many factors influencing the electric consumption of a public water system, including the size of the population served, the level of treatment of the water and wastewater, the method of distribution, and the climate. For the purposes of this report, village public water systems are split into two groups - those that have the capacity to provide complete plumbing to all or most residents, and those that do not.

Level I public water systems provide piped water and sewer to all city buildings and most homes. These systems usually have above-ground water mains, which need to be protected from freezing. Options include heating the water mains with electric heat tape, using a boiler to heat a glycol loop that runs through the water distribution system, or continuously pumping the water through a closed-loop distribution system. Figure 7 shows sample seasonal electric load profiles of Level I public water systems in seven different villages normalized by village population. 


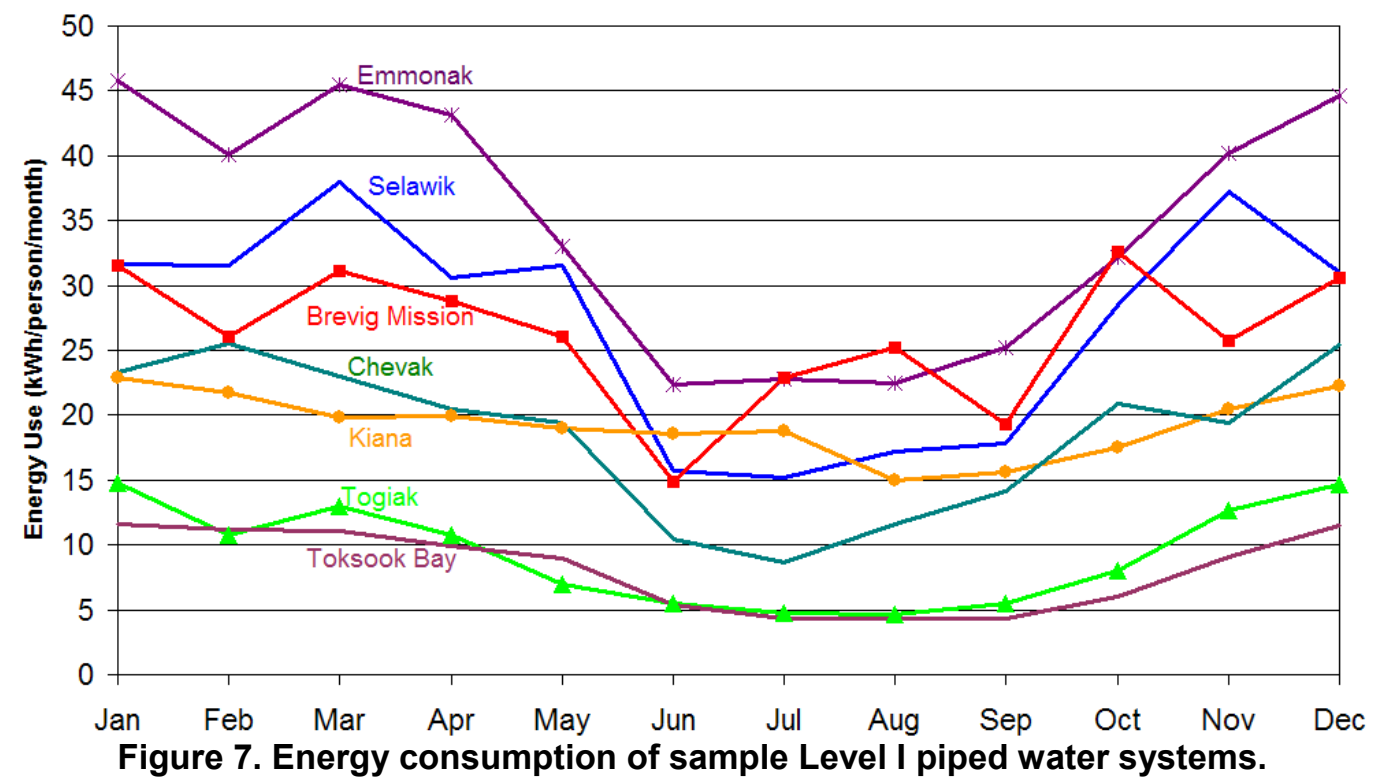

Even within this grouping, there is a significant amount of variation in electric usage throughout the year. This range in electric use is influenced by the use of electricity to provide heat, the pumping requirements of the facility, and the number of buildings served. The facilities that consume the most electricity per capita (Emmonak, Selawik, and Brevig Mission) use electricity for heating water mains. Chevak uses a gas-fired glycol loop to keep pipes from freezing, and Kiana has buried water and sewer mains. Togiak and Toksook Bay are the southernmost facilities, which do not have a threat of freezing water mains. Toksook Bay also has a gravity piped system with limited pump requirements. To distinguish among the range of Level I public water systems, these facilities are further divided into three categories based on electricity usage, as described in Table 3.

Table 3. Energy Consumption of Level I Public Water Systems

\begin{tabular}{|c|c|c|c|}
\hline Category: & \multicolumn{1}{|c|}{ Low } & \multicolumn{1}{c|}{ Medium } & \multicolumn{1}{c|}{ High } \\
\hline $\begin{array}{c}\text { Typical } \\
\text { Characteristics: }\end{array}$ & $\begin{array}{l}\text { Not all buildings or homes } \\
\text { are connected. Gravity } \\
\text { sewer system or surface } \\
\text { water source (less pumping } \\
\text { load). No electric heat. }\end{array}$ & $\begin{array}{l}\text { Most buildings and } \\
\text { homes are connected to } \\
\text { piped water and sewer. } \\
\text { No electric heat. }\end{array}$ & $\begin{array}{l}\text { Circulating water and } \\
\text { vacuum sewer system. } \\
\text { All buildings and homes } \\
\text { serviced. Arctic climate/ } \\
\text { electric heat tape on } \\
\text { pipes. }\end{array}$ \\
\hline Monthly & (kWh /person/month) & (kWh/person/month) & (kWh/person/month) \\
Consumption & 13.2 & 23.1 & 36.3 \\
Jan & 11.0 & 23.6 & 32.6 \\
Feb & 12.0 & 21.4 & 38.2 \\
Mar & 10.3 & 20.2 & 34.2 \\
Apr & 7.9 & 19.2 & 30.2 \\
May & 5.4 & 14.5 & 17.7 \\
June & 4.5 & 13.7 & 20.3 \\
July & 4.4 & 13.3 & 21.6 \\
Aug & 4.9 & 14.9 & 20.8 \\
Sept & 7.0 & 20.2 & 31.1 \\
Oct & 10.8 & 23.8 & 34.4 \\
Nov & 13.1 & & 35.4 \\
Dec & \multicolumn{3}{|c}{} \\
\hline \multicolumn{2}{|c|}{}
\end{tabular}


Figure 8 illustrates the monthly electric consumption of each category of Level I public water system listed in Table 3.

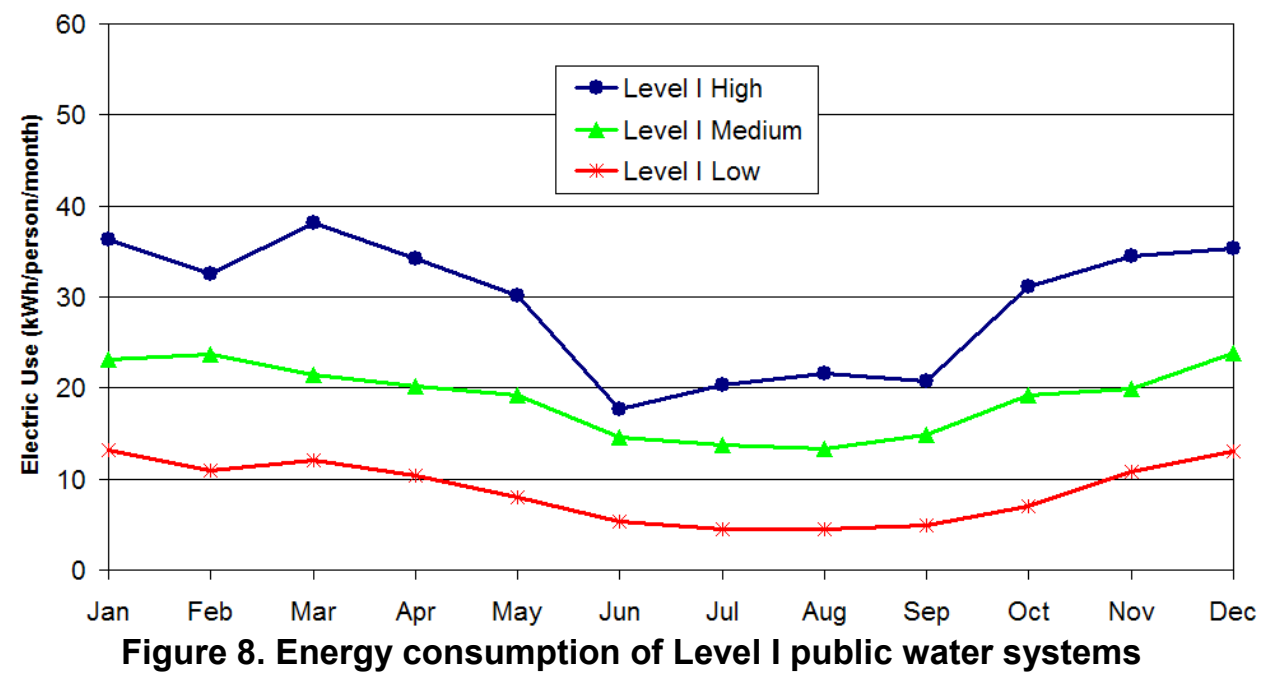

In Level II public water systems, water is pumped from a well or surface source, treated, and stored in an insulated tank. The water is supplied to a central washeteria where residents can collect water, bathe, and do laundry. Electric loads at these water treatment/washeteria facilities include pumps, washing machines and dryers, lights, and sometimes an electric sauna. In some villages, piped water is provided only to the school or health clinic. Level II systems do not treat wastewater; instead, each resident collects their wastewater in five-gallon "honey buckets" and hauls them to a sewage lagoon to be dumped. Almost half of Alaska's 200 native villages have this type of system where residents do not have running water or flush toilets in their homes (Rural Alaska Sanitation Coalition website, 2003). Figure 9 shows seasonal electric load profiles of several sample Level II systems.

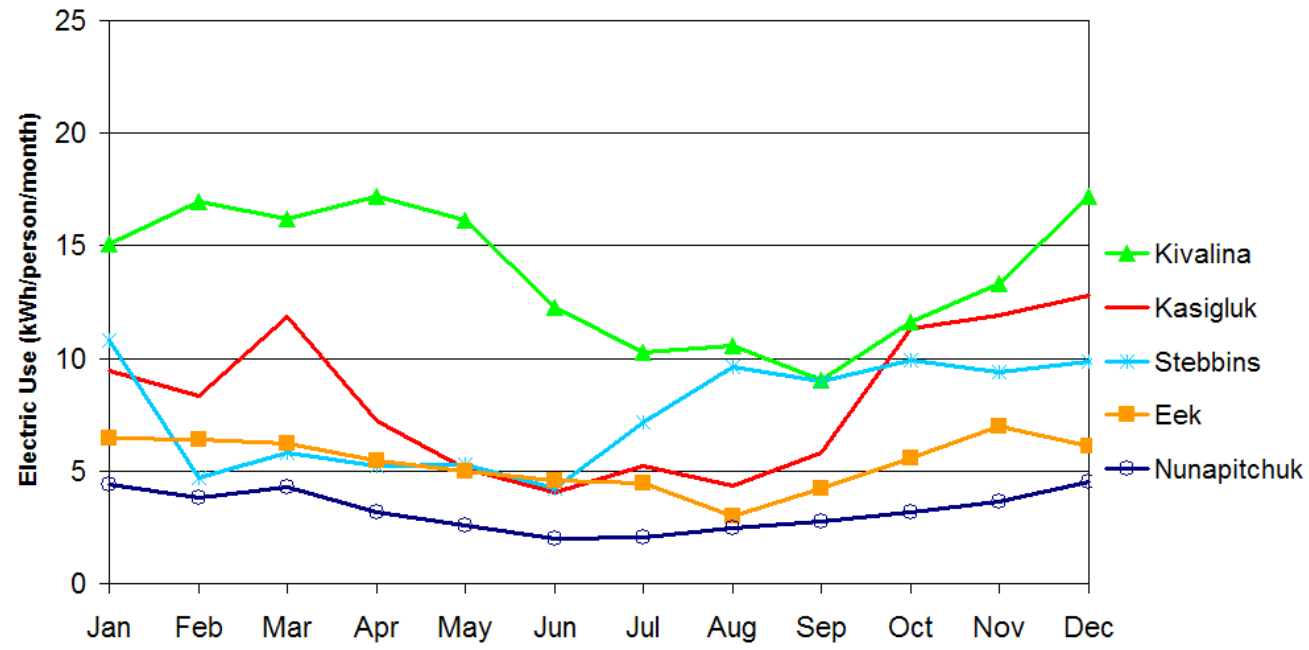

Figure 9. Energy consumption of Level II public water systems.

The range in electric use among Level II systems is influenced primarily by the types of services available in the washeteria and by the climate. For example, Stebbins is the most modern facility, offering electric saunas in addition to electric washers, propane dryers, and showers. Kivalina provides piped water to the health clinic, which accounts for its increased consumption per capita. It is also the northernmost facility, which requires electric heat tape to keep pipes from freezing. 
Eek, Nunapitchuk, and Toksook Bay are all located in the southwestern area of the state, which rarely experiences temperatures below freezing and thus have minimal electric heating requirements. To distinguish among the range of Level II public water systems, these facilities are further divided into two categories, as described in Table 4.

Table 4. Energy Consumption of Level II Public Water Systems

\begin{tabular}{|c|l|l|}
\hline Category: & \multicolumn{1}{|c|}{ Low } & \multicolumn{1}{|c|}{ High } \\
\hline Typical & $\begin{array}{l}\text { Water comes from } \\
\text { surface source. } \\
\text { Characteristics: } \\
\text { fimited washeteria } \\
\text { facilities. Limited use } \\
\text { of heat tape. }\end{array}$ & $\begin{array}{l}\text { Water pumped from well or from a long } \\
\text { distance surface source. Washeteria has } \\
\text { electric saunas, electric dryers, or } \\
\text { extended hours of operation. Extensive } \\
\text { use of heat tape. }\end{array}$ \\
\hline Monthly & & (kWh/person/month) \\
Consumption & (kWh/person/month) & 11.8 \\
Jan & 7.2 & 10.0 \\
Feb & 5.0 & 11.3 \\
Mar & 5.4 & 9.9 \\
Apr & 4.6 & 8.8 \\
May & 4.3 & 6.8 \\
June & 3.6 & 7.6 \\
July & 4.6 & 8.2 \\
Aug & 5.0 & 8.0 \\
Sept & 5.3 & 11.0 \\
Oct & 6.2 & 11.5 \\
Nov & 6.7 & 13.3 \\
Dec & 6.8 & \\
\hline
\end{tabular}

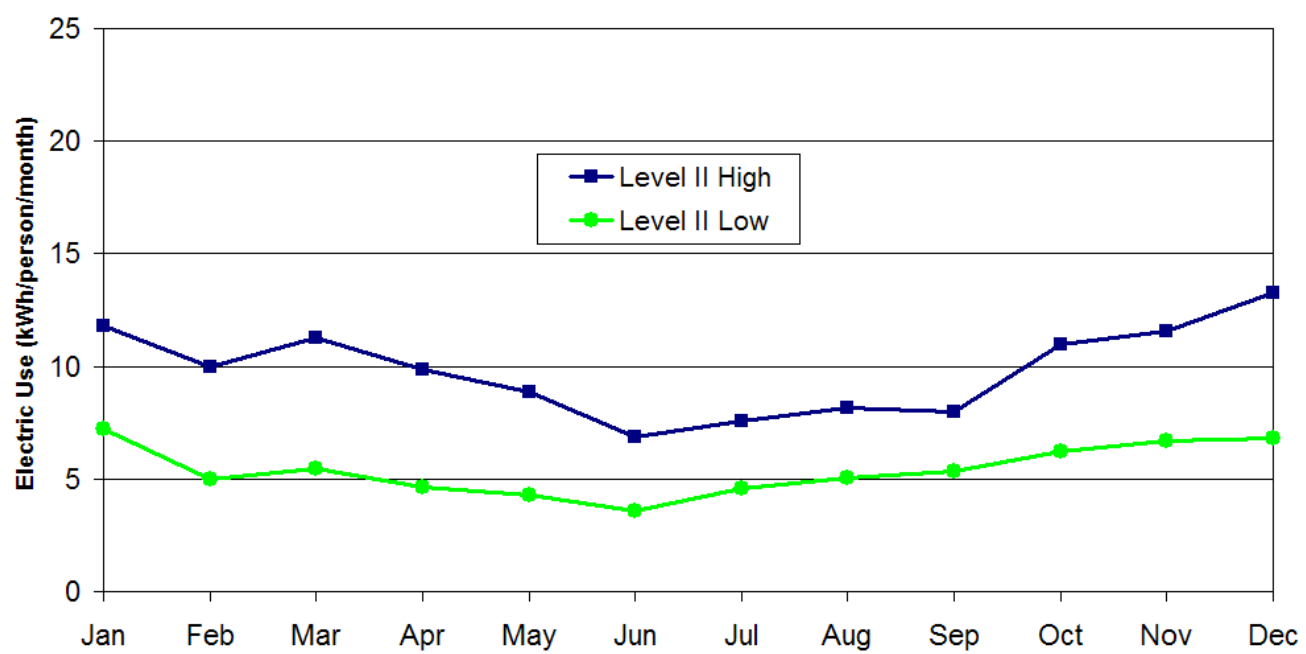

Figure 10. Energy consumption of Level II public water systems.

Figure 10 illustrates the energy consumption of the two categories of Level II public water systems. The monthly electric use values listed in Table 3 and Table 4 serve as the building block for the public water systems in the Alaska Village Electric Load Calculator. The electric consumption of public water systems can vary drastically from village to village. Most villages begin with a basic Level II system and gradually move towards a high Level I system as funding becomes available. 


\section{Village Health Clinics}

Each village typically operates a local health clinic staffed by community health aids. Regional clinics located in St. Mary's, Emmonak, Kiana, and Unalakeet, serve surrounding communities with a physician assistant or nurse practitioner. Patients requiring special care are flown to Anchorage or hospitals located in the hub cities of Kotzebue, Bethel, Nome, and Dillingham (Maniilaq Association, 2003). The per capita electric consumption of nine sample health clinics is shown in Figure 11.

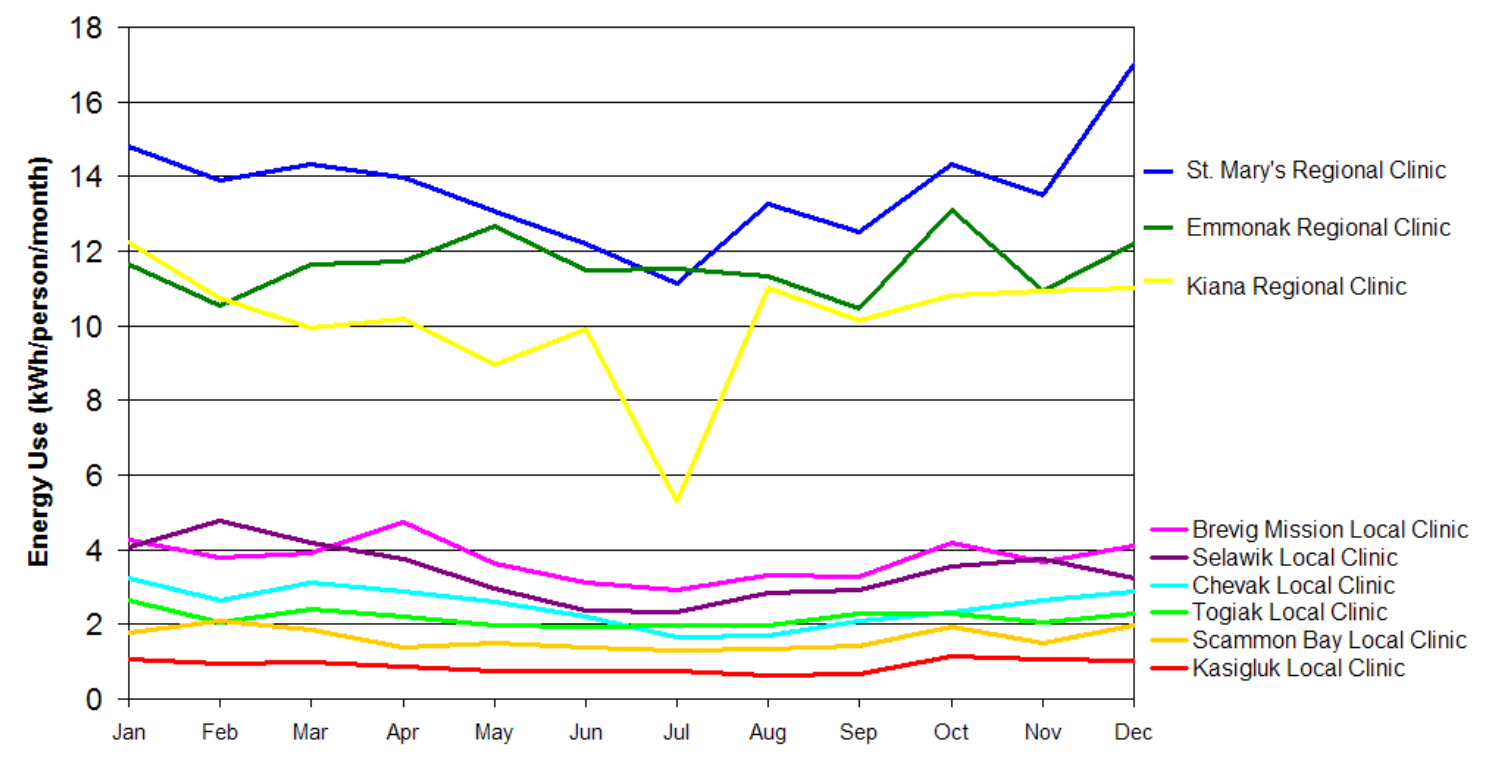

Figure 11. Energy consumption of sample village health clinics.

The distinction between electric requirements in regional and local health clinics is clear; regional clinics consume nearly six times more electricity per capita than local clinics. It should be noted that only one year of data was available from the Kiana regional clinic so it is unknown if the drop in consumption during July is typical. It is assumed that the actual consumption is closer to $9 \mathrm{kWh}$ per person during July. The health clinic sector for rural villages is divided into two categories, as described in Table 5.

Table 5. Electric Consumption for Village Health Clinics

\begin{tabular}{|c|c|c|}
\hline Category: & Local clinic & Regional clinic \\
\hline Monthly Consumption & (kWh/person/month) & (kWh/person/month) \\
Jan & 1.9 & 12.9 \\
Feb & 1.7 & 11.7 \\
Mar & 1.9 & 12.0 \\
Apr & 1.7 & 12.0 \\
May & 1.5 & 11.6 \\
June & 1.4 & 11.2 \\
July & 1.3 & 10.6 \\
Aug & 1.3 & 11.9 \\
Sept & 1.4 & 11.0 \\
Oct & 1.7 & 12.8 \\
Nov & 1.7 & 11.8 \\
Dec & 1.8 & 13.4 \\
\hline
\end{tabular}




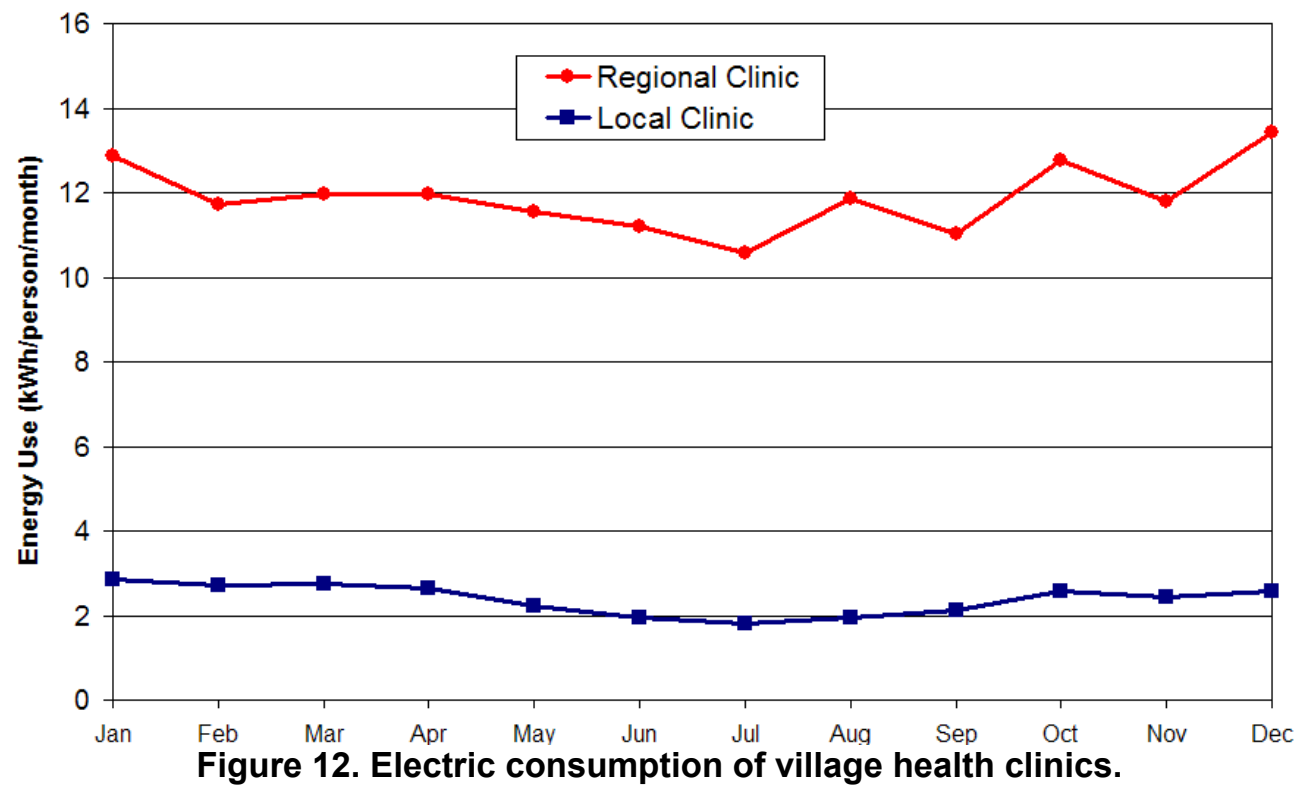

The monthly electric consumption of the local and regional health clinics is listed in Table 5 and illustrated in Figure 12. These values serve as the building block for the health clinic sector used in the Alaska Village Electric Load Calculator.

\section{City and Government Sector Loads}

The city and government sector, which includes city offices, post offices, native tribal offices, and community centers, makes up about $20 \%$ of a village's electric use. Seasonal electric load profiles of sample city/government buildings are shown in Figure 13.

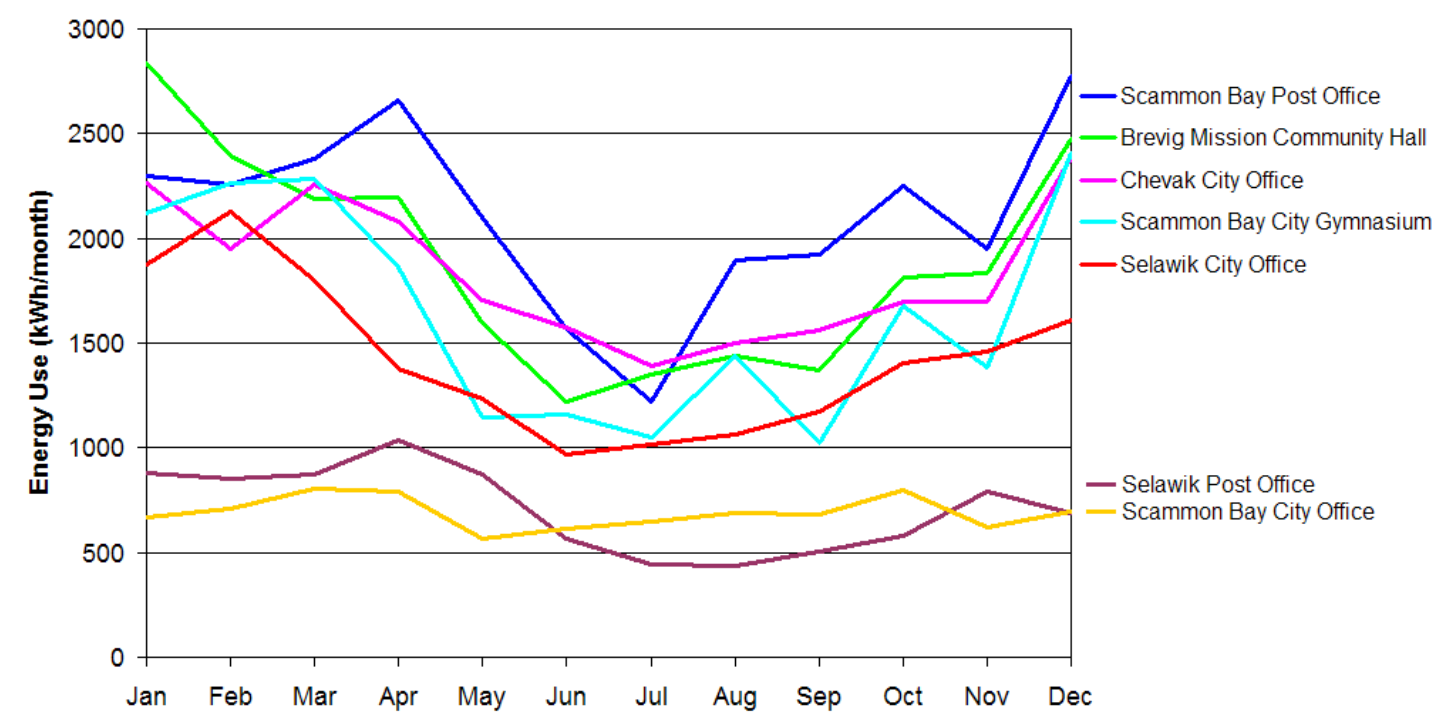

Figure 13. Energy consumption of sample city/government buildings. 
To distinguish among the range of electric use between city facilities, these loads are divided into two electric use categories, as described in Table 6 . The total city/government load in a village can be made up of a number of buildings from each category. Note that the monthly consumption is not normalized by city population as with other sectors, because the electric use of these facilities is not as dependent on population.

Table 6. Electric Consumption of City and Government Buildings

\begin{tabular}{|c|c|c|}
\hline Category: & Small & Large \\
\hline Examples: & $\begin{array}{c}\text { Post office, city office, } \\
\text { native office, FAA, DOT }\end{array}$ & $\begin{array}{c}\text { Gymnasium, community } \\
\text { center, large city office }\end{array}$ \\
\hline Monthly & (kWh/month) & $(\mathrm{kWh} /$ month) \\
Consumption & 774 & 2279 \\
Jan & 781 & 2198 \\
Feb & 837 & 2183 \\
Mar & 913 & 2035 \\
Apr & 720 & 1556 \\
May & 592 & 1299 \\
June & 544 & 1205 \\
July & 564 & 1468 \\
Aug & 595 & 1410 \\
Sept & 686 & 1768 \\
Oct & 706 & 1664 \\
Nov & 692 & 2330 \\
Dec & & \\
\hline
\end{tabular}

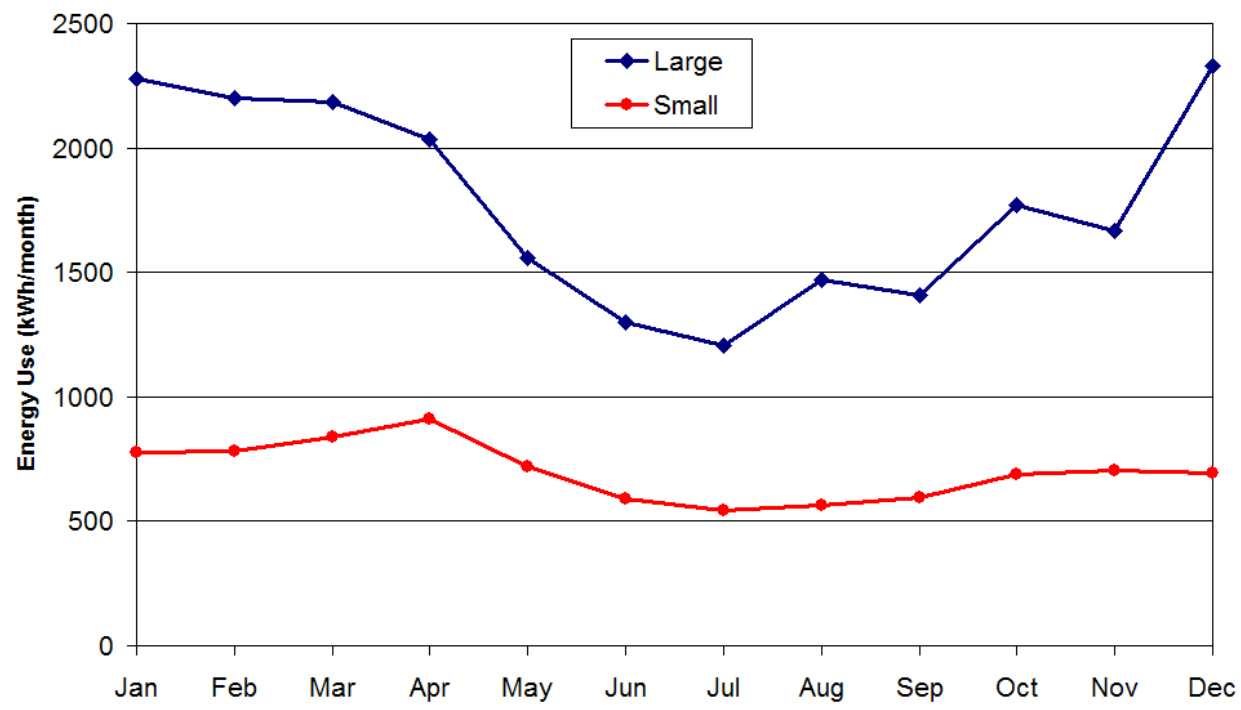

Figure 14. Energy consumption of city buildings.

The monthly electric consumption of the typical city facilities is listed in Table 6 and illustrated in Figure 14. These values make up the building block for the each city/government building in the Alaska Village Electric Load Calculator. 


\section{Commercial Sector Loads}

The commercial sector makes up about $15 \%$ of a village's electricity consumption. Most villages have one general store, while larger villages have up to four different stores. The commercial sector also consists of various business offices and warehouses. The per capita electric load profile for six sample commercial facilities is shown in Figure 15.

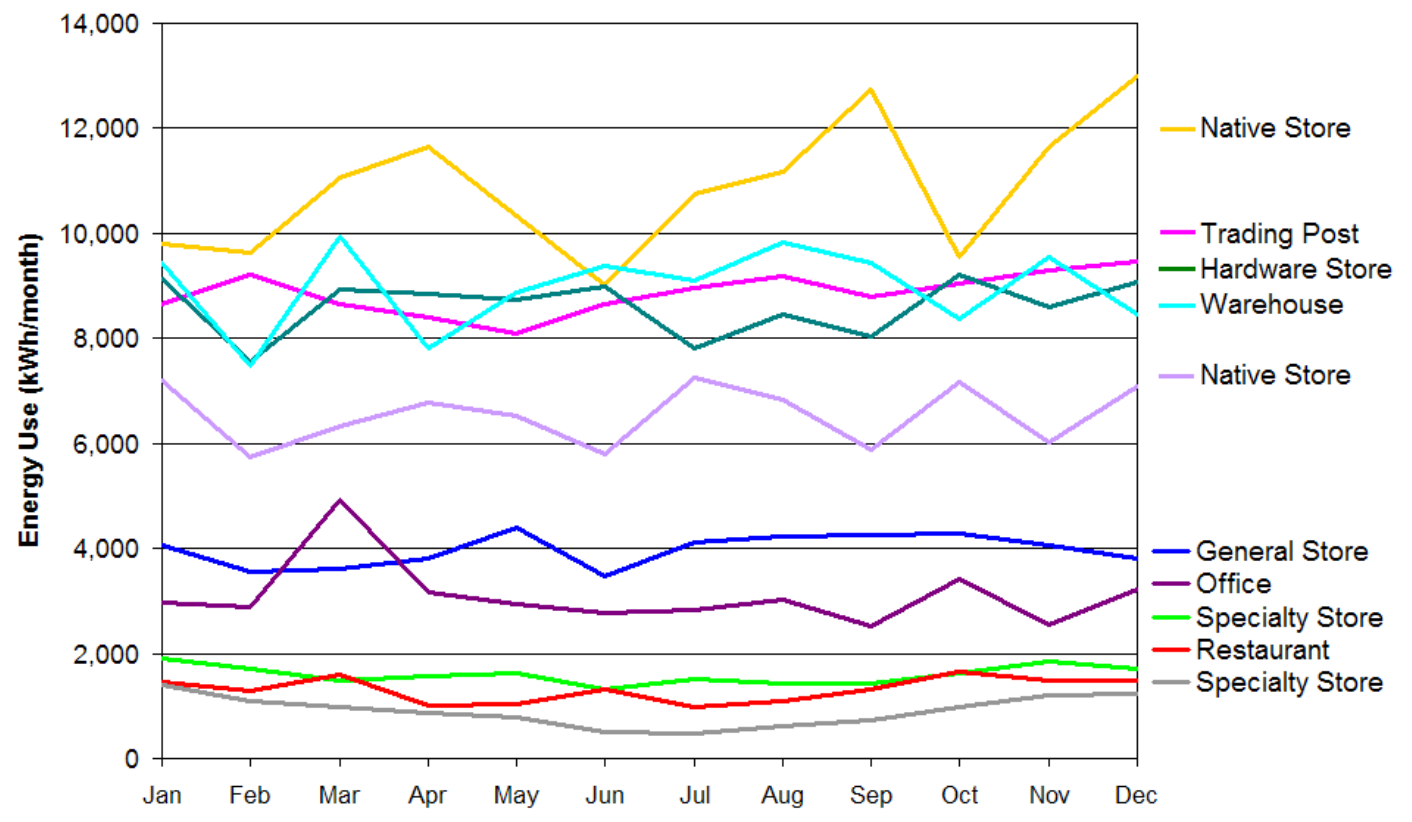

Figure 15. Energy consumption of sample commercial facilities.

To distinguish among the range of electric use between commercial facilities, these loads are divided into two categories, as described in Table 7. Note that the monthly electric consumption is not normalized by population as with other sectors, because the energy use in these facilities is not dependent on community size.

Table 7. Electric Consumption of Commercial Facilities

\begin{tabular}{|c|c|c|}
\hline Category: & Small Business & Large Commercial \\
\hline Examples: & $\begin{array}{c}\text { Office, restaurant, } \\
\text { specialty store }\end{array}$ & $\begin{array}{c}\text { Hardware store, native store, general } \\
\text { store, warehouse, construction company }\end{array}$ \\
\hline Monthly Consumption & $(\mathrm{kWh} /$ month $)$ & $(\mathrm{kWh} /$ month $)$ \\
Jan & 2,363 & 9,653 \\
Feb & 2,108 & 9,022 \\
Mar & 2,520 & 9,473 \\
Apr & 2,083 & 8,875 \\
May & 2,151 & 8,579 \\
June & 1,875 & 8,070 \\
July & 1,988 & 8,533 \\
Aug & 2,081 & 8,925 \\
Sept & 2,053 & 9,150 \\
Oct & 2,394 & 10,581 \\
Nov & 2,226 & 10,208 \\
Dec & 2,291 & 10,732 \\
\hline
\end{tabular}


The monthly electric consumption of typical commercial facilities is summarized in Table 7 and illustrated in Figure 16. One of these load profiles is added for each commercial facility in a village to make up the building block for the commercial sector that is used in the Alaska Village Electric Load Calculator.

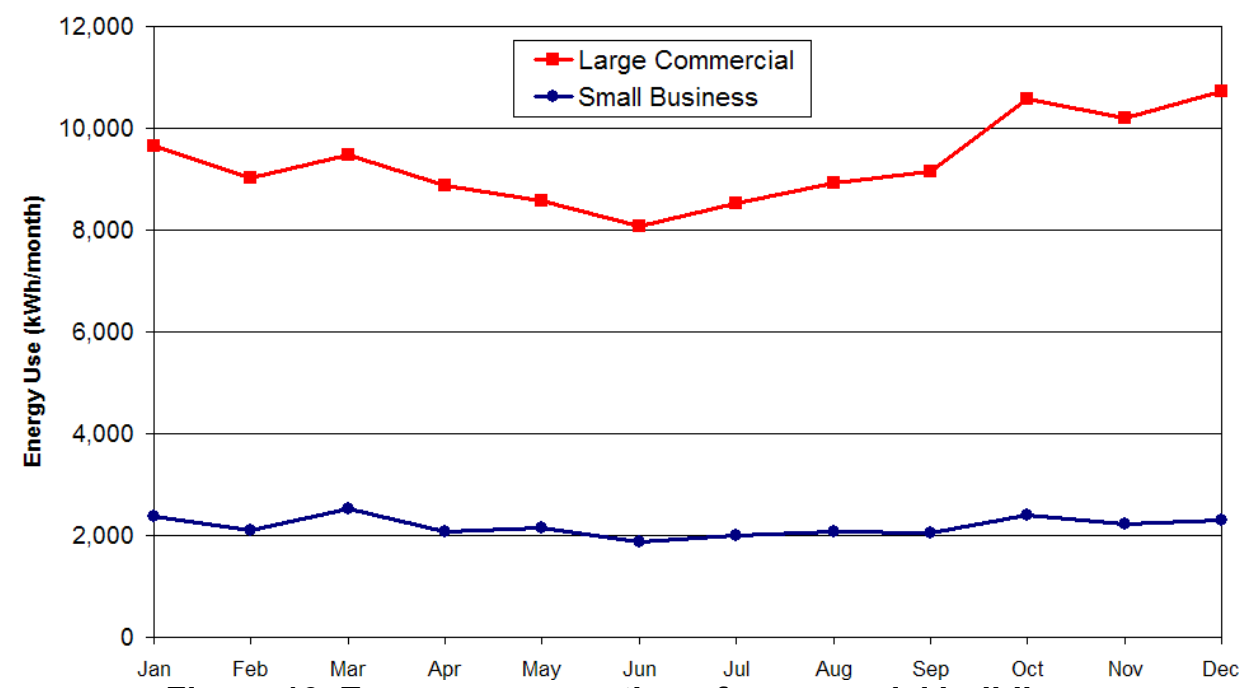

Figure 16. Energy consumption of commercial buildings.

It is important to note that the seasonal profile for these commercial facilities is fairly steady. Most, but not all, commercial facilities seem to follow this pattern. For example, fish-processing plants have their peak use in the summer and use considerably less electricity in the winter. As data from these facilities were not available, the electric use of unique commercial facilities such as these would need to be added to the Village Electric Load Calculator separately.

\section{Communications Facilities}

Most villages have phone, cable, and internet service, although not all homes are connected. The monthly electric consumption of sample communication service providers in six different villages is shown in Figure 17. 


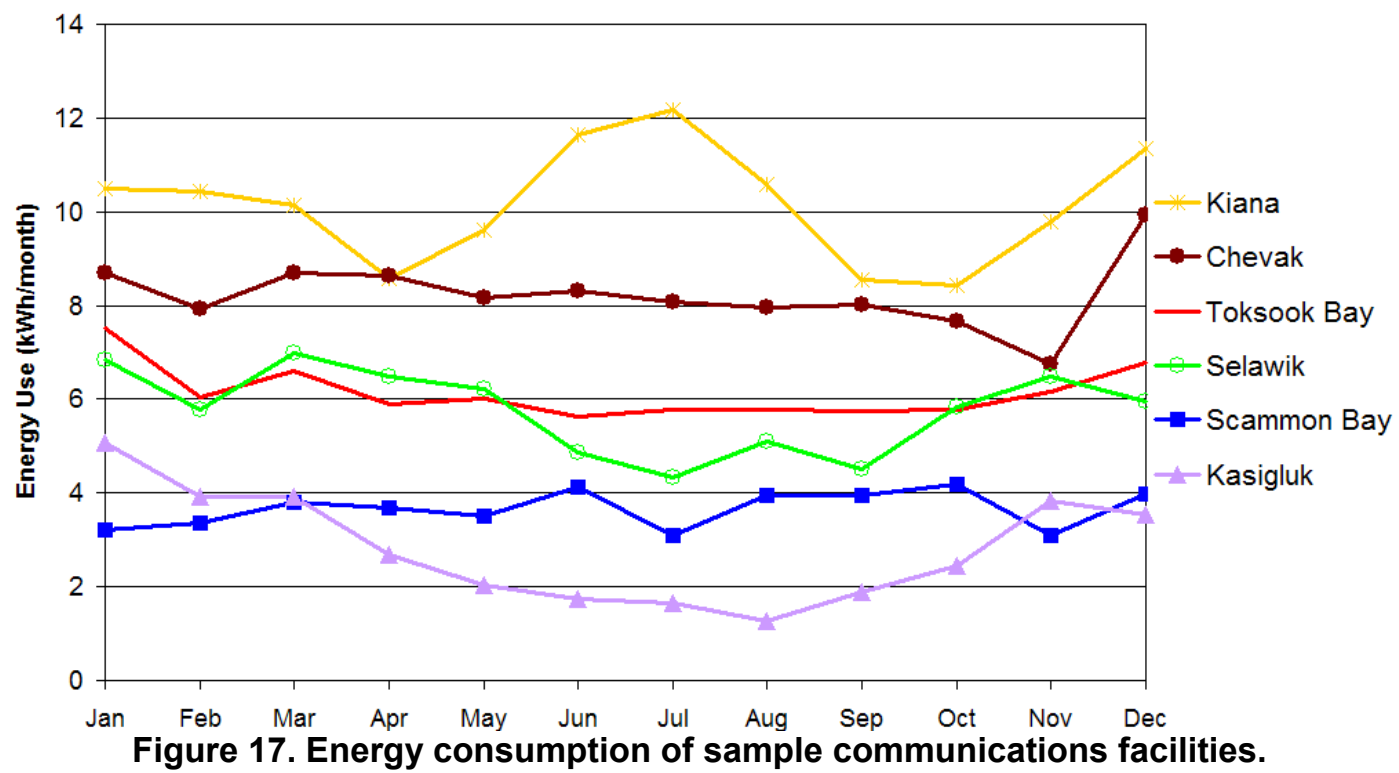

The electric load of the communications service providers is relatively steady throughout the year. The communications sector is divided into two categories: basic and advanced, as detailed in Table 8. Note that the energy consumption is not normalized by population.

Table 8. Energy Consumption of Communications Sector

\begin{tabular}{|c|c|c|}
\hline Category: & Basic & Advanced \\
\hline Characteristics: & $\begin{array}{c}\text { Internet and/or } \\
\text { cable }\end{array}$ & $\begin{array}{c}\text { Internet, cable, } \\
\text { radio tower }\end{array}$ \\
\hline Monthly Consumption & $(\mathrm{kWh} /$ month $)$ & $(\mathrm{kWh} /$ month $)$ \\
Jan & 2,303 & 6,870 \\
Feb & 2,060 & 5,996 \\
Mar & 2,202 & 6,870 \\
Apr & 1,975 & 6,502 \\
May & 1,919 & 6,373 \\
June & 1,860 & 6,698 \\
July & 1,807 & 6,231 \\
Aug & 1,800 & 6,371 \\
Sept & 1,707 & 6,204 \\
Oct & 1,882 & 5,927 \\
Nov & 2,032 & 5,363 \\
Dec & 2,204 & 7,552 \\
\hline
\end{tabular}

The monthly energy consumption of the different types of communications facilities is listed in Table 8 and illustrated in Figure 18. These values serve as the building block for the communications sector that is used in the Alaska Village Electric Load Calculator. 


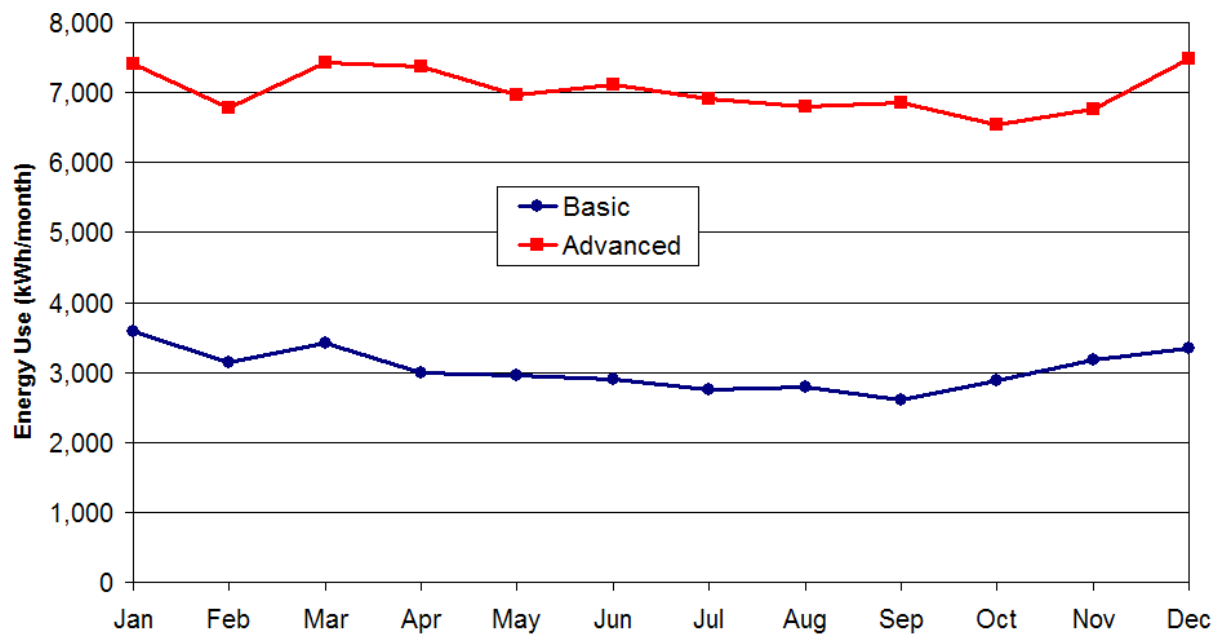

Figure 18. Energy consumption of communications sector loads.

\section{Other Loads}

Other loads within a village may include an armory, streetlights, and churches. These electric loads are estimated to add about 3\%-7\% to the total village load. An option for specifying the amount of other loads is included in the Village Electric Load Calculator. The value that is input depends on the number of additional facilities in the village that are not accounted for in the community sectors described previously.

\section{Daily Village Load Profiles}

Similar to the process described above, a daily load profile analysis can be performed that separates the primary loads and looks at the daily changes in these loads. At the time of this writing, time series data were not available for specific electricity consumers. Instead, what follows is an analysis of the daily electric load profiles for eight different villages for which high quality data were available. The villages are: Selawik, Chevak, Kiana, Gambell, Ambler, Noorvik, Scammon Bay, and New Stuyahok. Each of these communities is a different size and provides different levels of community services. The goal is to use this information, along with knowledge of the seasonal load profiles described in the previous sections, to make general estimates as to the electric usage in a typical Alaskan village. This information will then be incorporated into the Alaska Village Electric Load Calculator to obtain an hourly electric load data set.

The data used in this analysis were obtained from power stations where AVEC recorded the instantaneous electric load once every 15 minutes. The four data points within each hour were averaged to create an hourly electric load profile for each year. Figure 19 displays the daily electric load profiles of an average day in each month for the village of Selawik. These daily profiles were created by averaging each hour over every day of the month. 


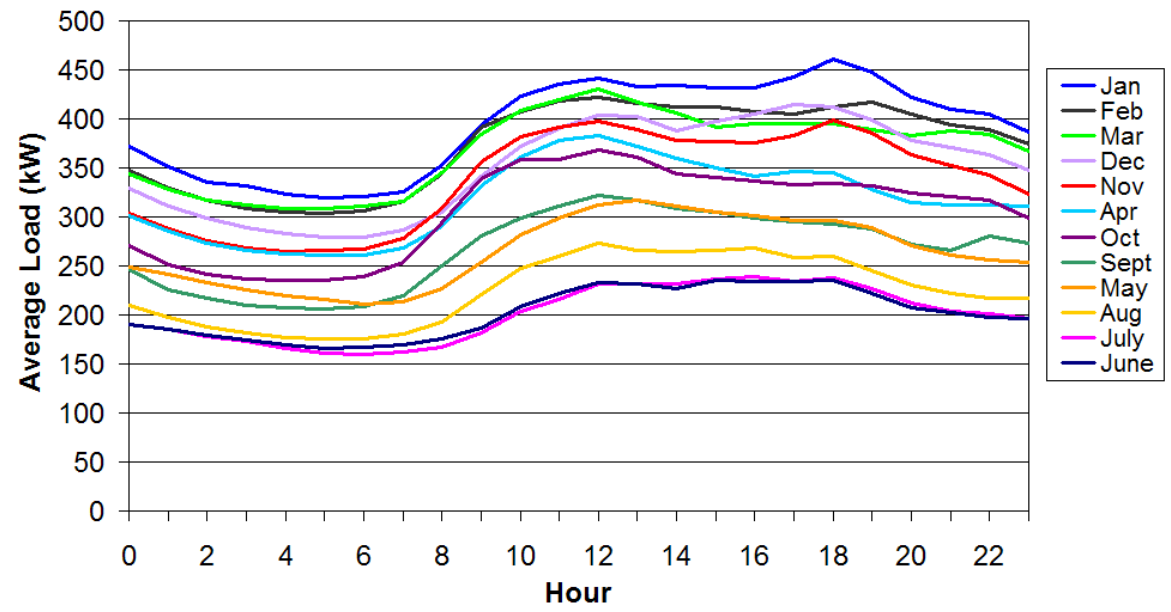

Figure 19. Daily load profiles for Selawik, Alaska.

As one would expect, the daily load profile for the community depends on the season. Villages consume more electricity per capita throughout the day during the winter months than in the summer months, due primarily to increased lighting and electric heating loads. However, while the magnitude of the load fluctuates from summer to winter, the shape of the profile changes little. The difference is that on winter days, there tends to be two peaks - one around 11:00 a.m. and the other around 6:00 p.m., while on the summer days, the load remains fairly constant between those hours. Also, the range between the minimum and peak load of the day is shallower during the summer months than the winter months.

Comparing the shape of the daily profiles between villages results in clear similarities. To demonstrate this, the hourly electric load values for the eight villages are normalized by village population. Then each hourly value was divided by the peak load of the day so that each load profile peaks at a value of 1 . Figure 20 compares the January daily load profiles for the eight different communities, and Figure 21 compares the July daily load profiles. It is important to note that the shape of the profile in each month is similar between villages. The villages represent a range of size, location, and community characteristics, yet the pattern of electric usage throughout the day is comparable. Therefore, it is expected that the shape of the daily profile in one village can be used to create a reasonable estimate of the daily profile in another village. 

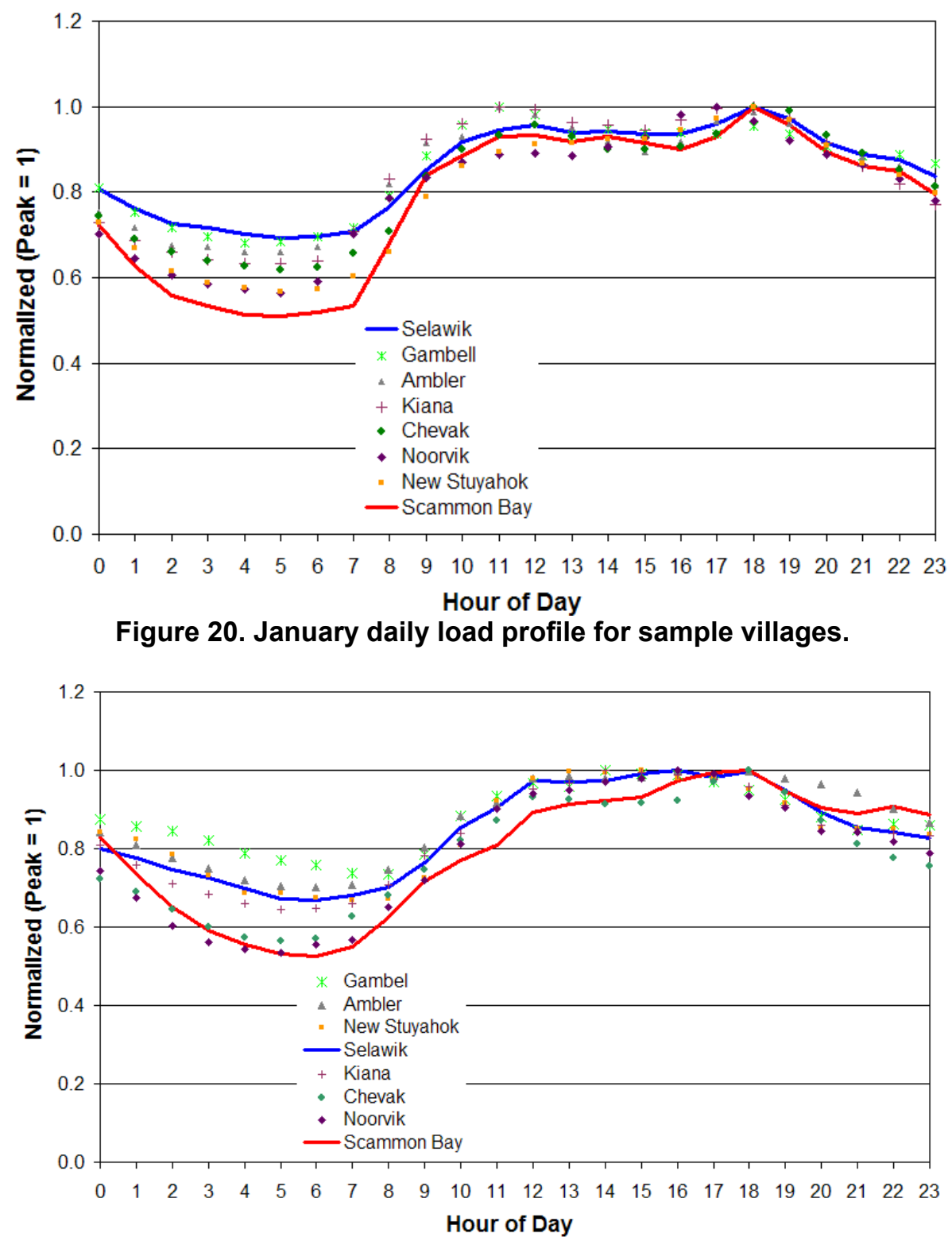

Figure 21. July daily load profiles for sample villages.

In each graph there is a divergence in energy usage during the early hours of the day. This is most likely due to the level of street lighting in the village and the use of electric heat tape on water mains. Selawik, located in the northernmost part of Alaska, represents a village that has a higher demand for early morning heating and lighting loads, even during summer months. Scammon Bay, located along the southern coast of Alaska, represents a village that has a lower demand for heating and lighting in the early morning hours. The hourly electric use patterns from these two villages can be used to create hourly load data for other villages. The magnitude of the daily profiles is adjusted by scaling the profile up or down depending on the monthly electric consumption determined from the seasonal load profile described in the previous section. 


\section{HOW TO USE THE ALASKA VILLAGE ELECTRIC LOAD CALCULATOR}

There are two steps to using the Alaska Village Electric Load Calculator: 1) estimate the total seasonal electric load profile for the village, and 2) use the seasonal profile to adjust each month of hourly electric data from a representative village. An example of how to use the load calculator is shown below for the village of Brevig Mission.

Step 1 is to estimate the village seasonal load profile by adding the profiles of each of the individual sectors described previously. Table 9 summarizes the village characteristics that determine which category of each community sector that the Village Electric Load Calculator uses.

Table 9. Electric Load Calculator Inputs for Brevig Mission

\begin{tabular}{|c|c|}
\hline Village Characteristics & Value \\
\hline Population & 314 \\
\hline \# of Small Businesses & 2 \\
\hline $\begin{array}{r}\text { \# of Large Commercial } \\
\text { Businesses }\end{array}$ & 0 \\
\hline \# of Community Buildings & 2 \\
\hline \# of Government Offices & 1 \\
\hline Median Household Income & Low \\
\hline K-12 School & High \\
\hline Public Water System & Level 1 High \\
\hline Health Clinic & Local \\
\hline Communications & Basic \\
\hline Other Loads & $5 \%$ \\
\hline
\end{tabular}


The monthly electric consumption of each community sector that makes up the total village load profile for Brevig Mission is shown in Figure 22.

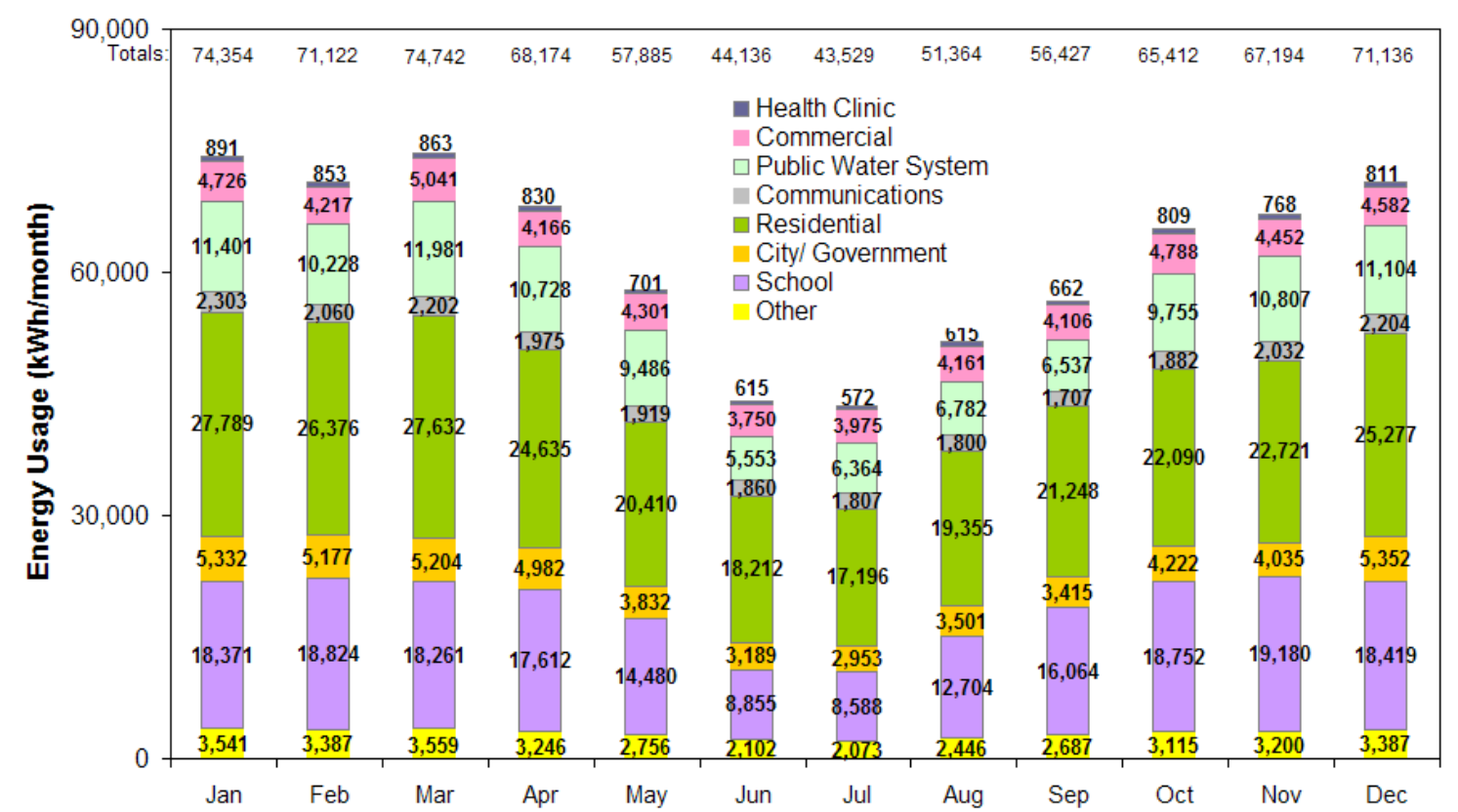

Figure 22. Example results from the Alaska Village Electric Load Calculator.

The Second step in using the Alaska Village Electric Load Calculator is to create the daily electric load data set. Because Brevig Mission is located in northern Alaska, a year of hourly data measured from the village of Selawik (also located in northern Alaska) is used as a baseline. The hourly values are then scaled up or down so that the total energy use for each month matches the values estimated from the Village Electric Load Calculator in Step 1. The resulting hourly data set is shown in Figure 23.

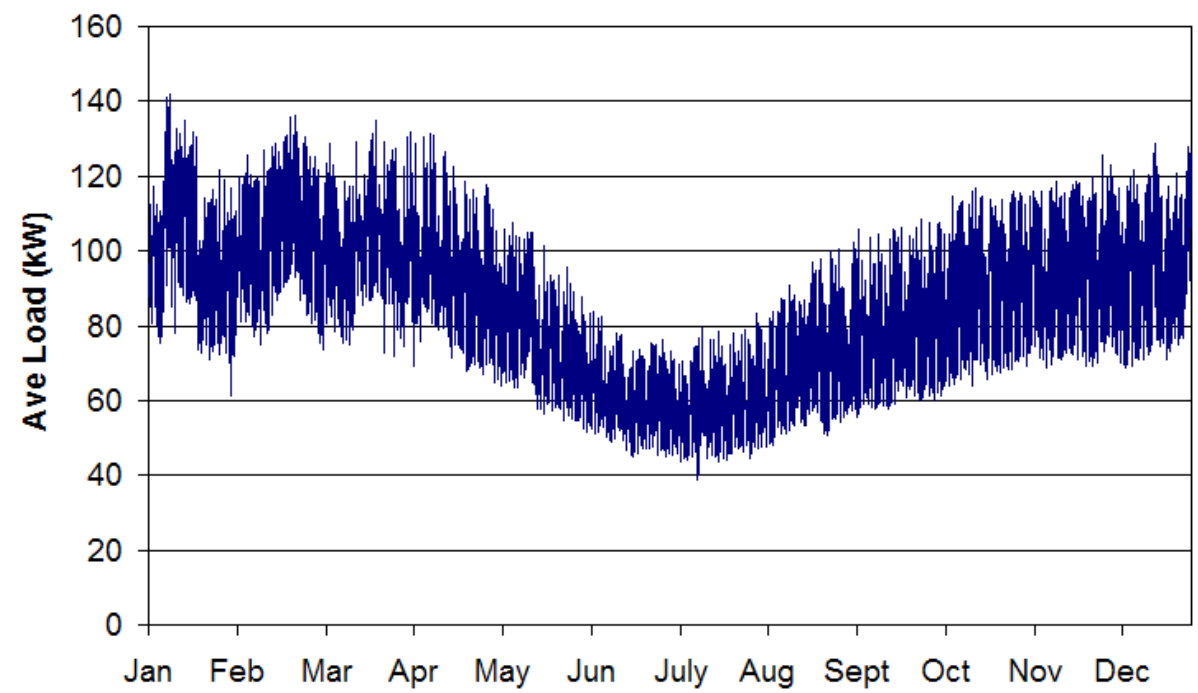

Figure 23. Estimated hourly electric load in Brevig Mission. 


\section{Verification of Village Electric Load Calculator Method}

Figure 24 shows the estimated electric load profile determined from the load calculator method versus the actual load profile from billing records for the village of Brevig Mission, Alaska.

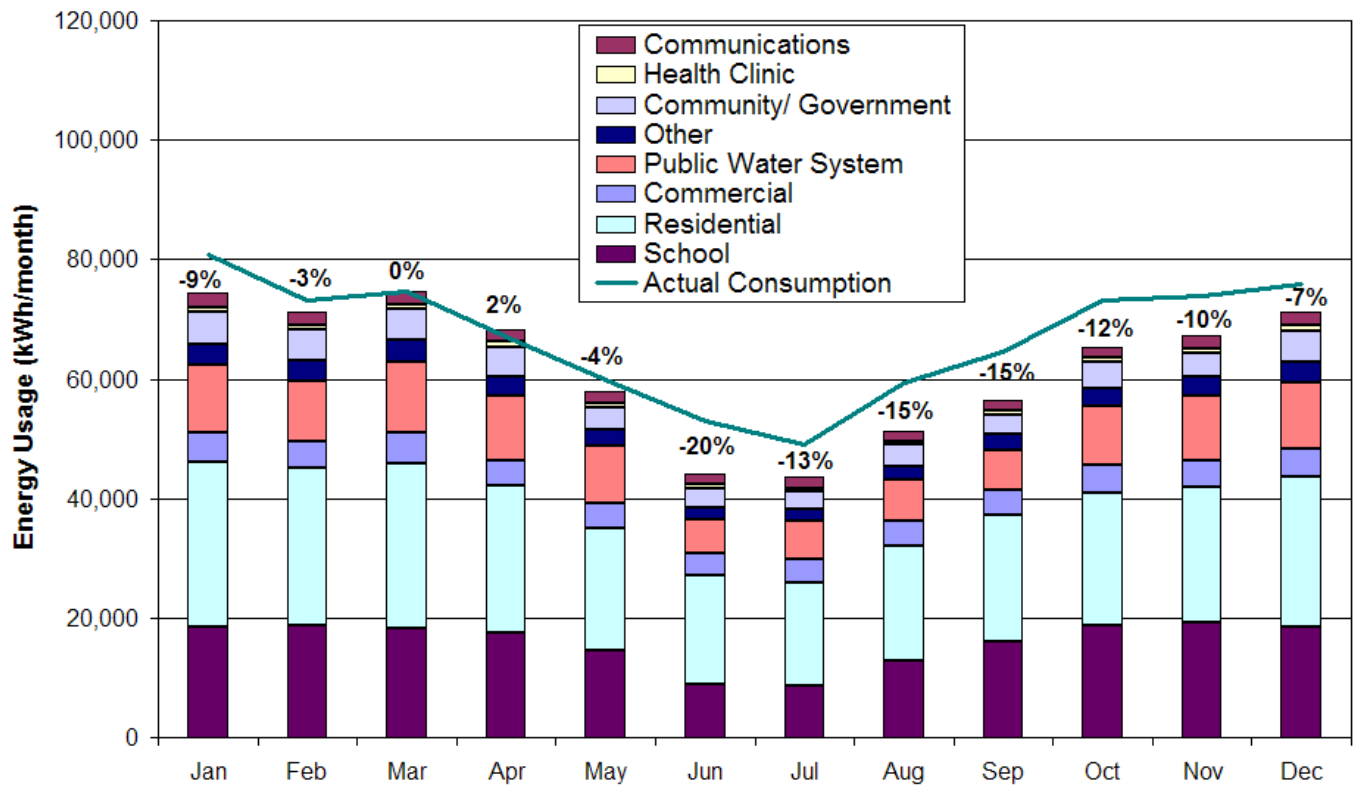

Figure 24. Brevig Mission 2003 estimate versus actual consumption.

On average, the Village Electric Load Calculator underestimates the actual consumption by 9\%. Figures 25 through 27 show other village examples comparing the estimated load with actual data. Each example shows a table of the load calculator inputs and a graph of the results. The graph includes the electric consumption of the community facilities that make up the estimated village load, a line showing the actual measured village consumption, and the percent difference between the estimated and actual load for each month.

Table 10. Village Electric Load Calculator Inputs for the Village of Toksook Bay

\begin{tabular}{|l|c|}
\hline \multicolumn{1}{|c|}{ Village Characteristic } & Value \\
\hline Population & 550 \\
\hline \# of Small Businesses & 3 \\
\hline $\begin{array}{l}\text { \# of Large Commercial } \\
\text { Businesses }\end{array}$ & 0 \\
\hline \# of Community Buildings & 2 \\
\hline \# of Government Offices & 3 \\
\hline Median Household Income & Medium \\
\hline
\end{tabular}

\begin{tabular}{|l|c|}
\hline \multicolumn{1}{|c|}{$\begin{array}{c}\text { Village } \\
\text { Characteristic }\end{array}$} & Value \\
\hline K-12 School & Medium \\
\hline Public Water System & Level II Low \\
\hline Health Clinic & Local \\
\hline Communications & Basic \\
\hline Other Loads & $1 \%$ \\
\hline
\end{tabular}




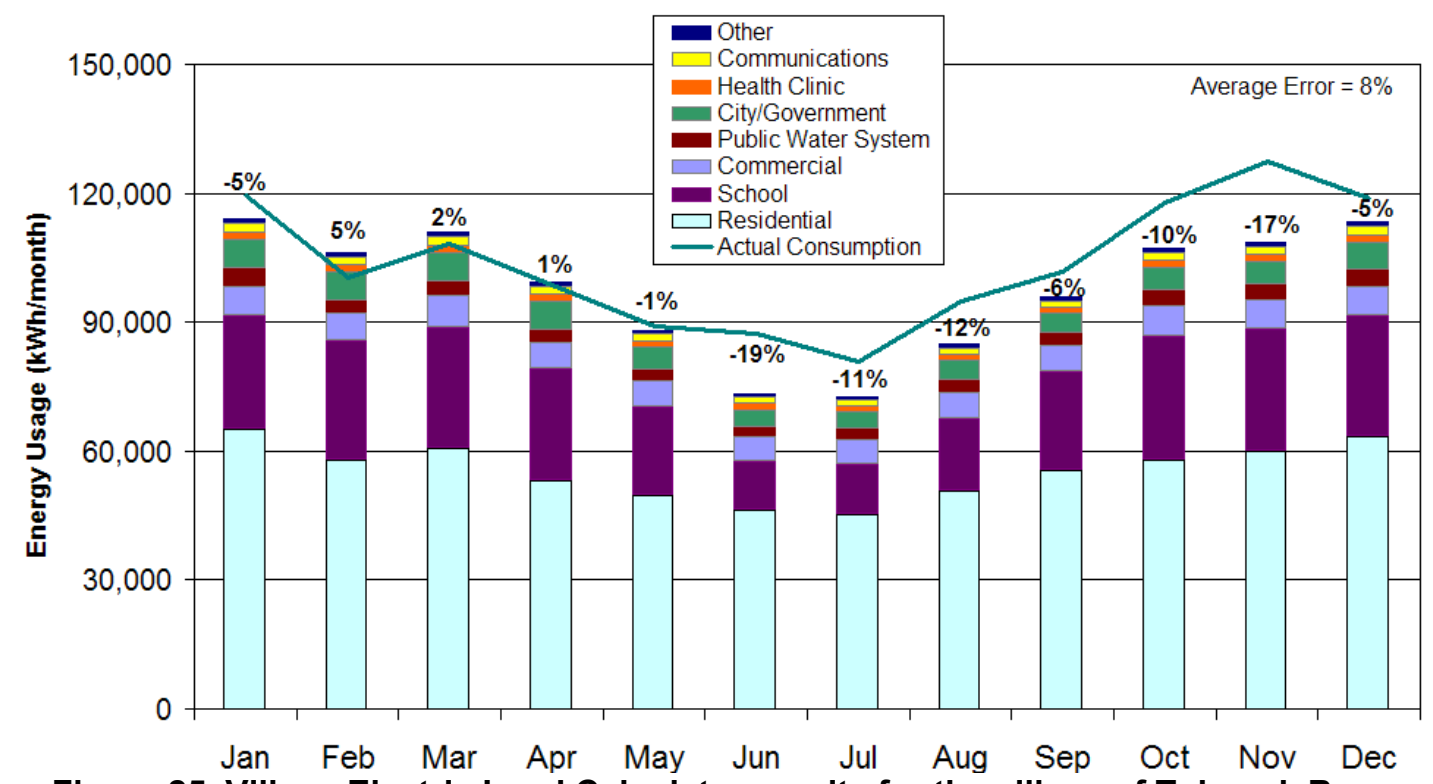

Figure 25. Village Electric Load Calculator results for the village of Toksook Bay.

The average error between the estimated load and actual load is $8 \%$.

Table 11. Village Electric Load Calculator Inputs for the Village of Mekoryuk

\begin{tabular}{|l|c|}
\hline \multicolumn{1}{|c|}{ Village Characteristic } & Value \\
\hline Population & 204 \\
\hline \# of Small Businesses & 3 \\
\hline \# of Large Commercial Businesses & 1 \\
\hline \# of Community Buildings & 1 \\
\hline \# of Government Offices & 5 \\
\hline Median Household Income & Medium \\
\hline
\end{tabular}

\begin{tabular}{|l|c|}
\hline \multicolumn{1}{|c|}{$\begin{array}{c}\text { Village } \\
\text { Characteristic }\end{array}$} & Value \\
\hline K-12 School & Medium \\
\hline Public Water System & Level I Medium \\
\hline Health Clinic & Local \\
\hline Communications & Basic \\
\hline Other Loads & $5 \%$ \\
\hline
\end{tabular}

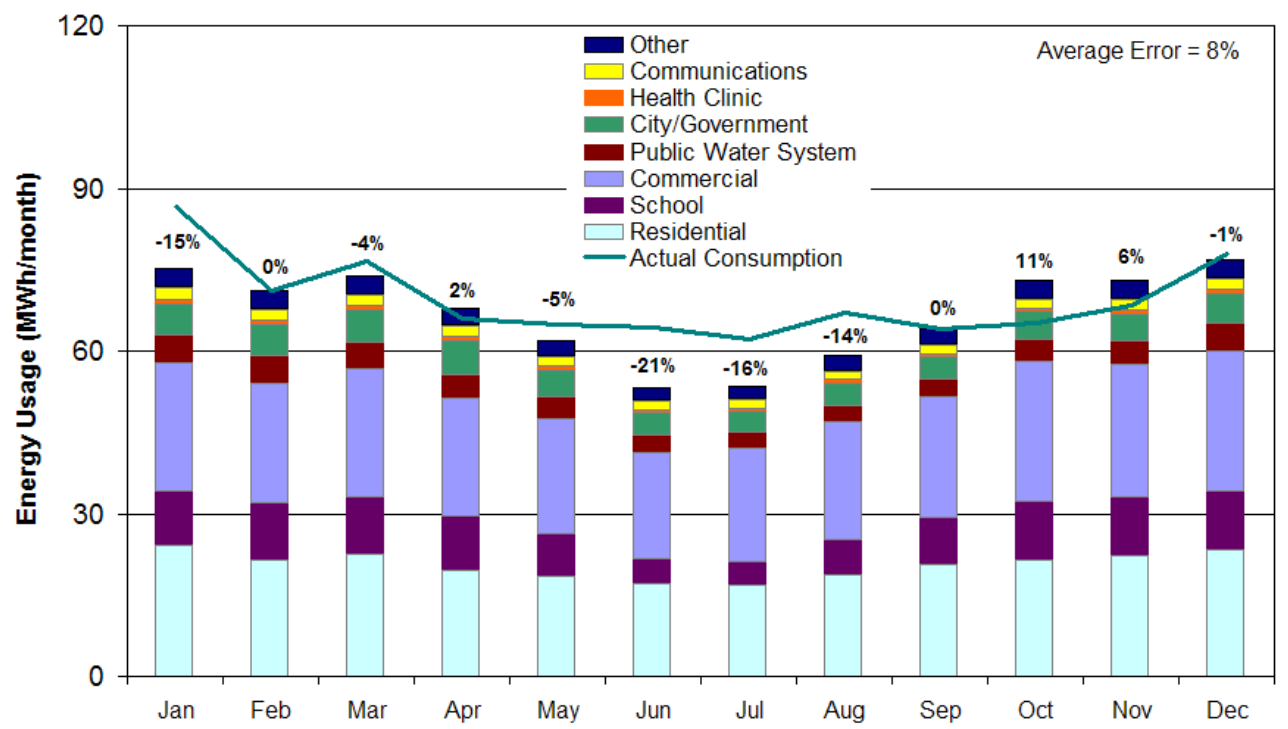

Figure 26. Village Electric Load Calculator results for the village of Mekoryuk. 
The average error between the estimated load and actual load is $8 \%$.

Table 12. Village Electric Load Calculator Inputs for the Village of Kiana

\begin{tabular}{|l|c|}
\hline \multicolumn{1}{|c|}{ Village Characteristic } & Value \\
\hline Population & 400 \\
\hline \# of Small Businesses & 4 \\
\hline \# of Large Commercial Businesses & 2 \\
\hline \# of Community Buildings & 1 \\
\hline \# of Government Offices & 3 \\
\hline Median Household Income & High \\
\hline
\end{tabular}

\begin{tabular}{|l|c|}
\hline Village Characteristic & Value \\
\hline K-12 School & High \\
\hline Public Water System & Level I High \\
\hline Health Clinic & Local \\
\hline Communications & Basic \\
\hline Other Loads & $5 \%$ \\
\hline
\end{tabular}

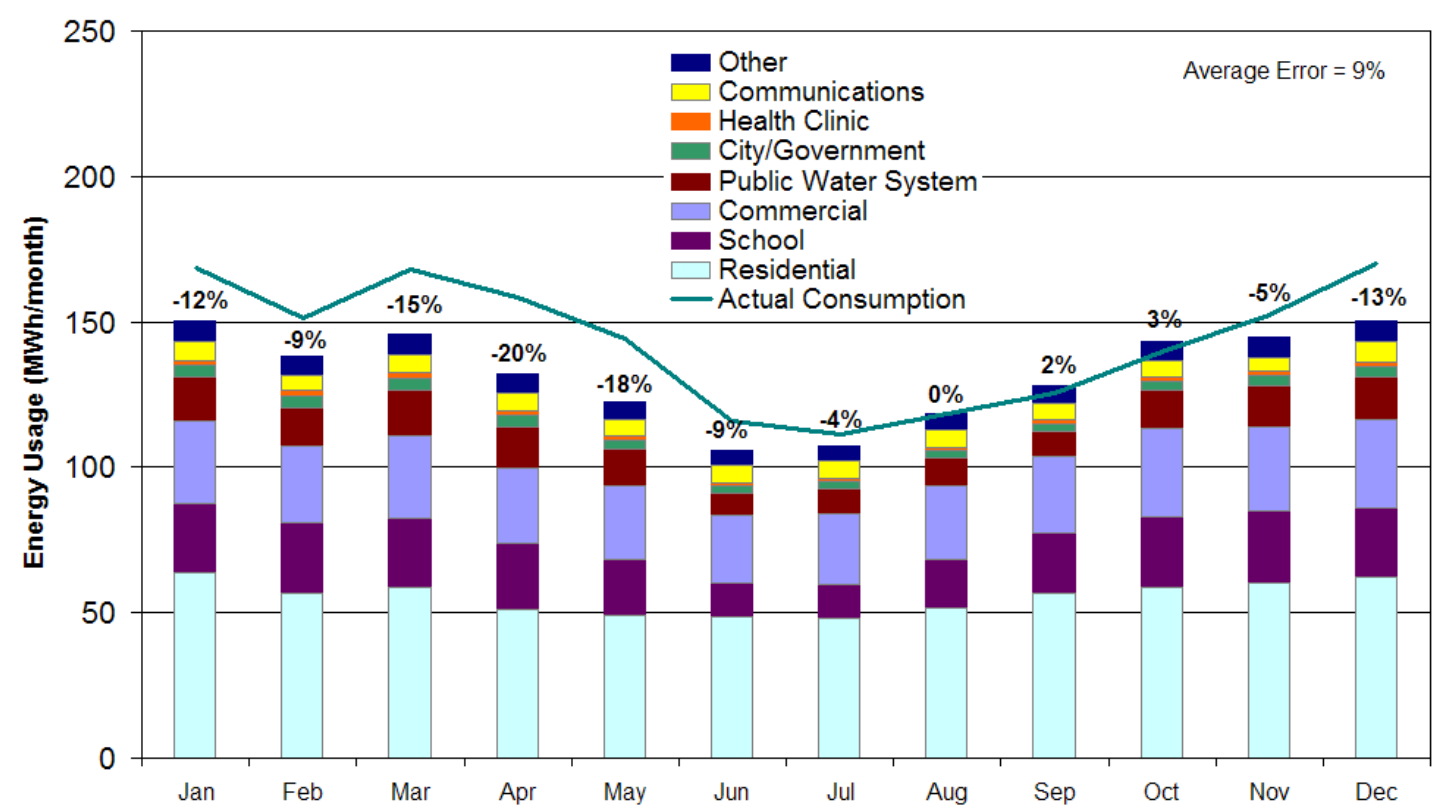

Figure 27. Village Electric Load Calculator results for the village of Kiana.

The average error between the estimated electric load and the actual electric load for the Kiana example is $9 \%$.

To evaluate the ability of the Village Electric Load Calculator to predict an increase in energy consumption due to the addition of a facility in a community, we used the village of Selawik. Selawik completed a series of construction projects between 1996 and 2001: a piped water and sewer system project was begun in 1997 and completed in 2000, a village health clinic was constructed in 1997, and a new K-12 school came online in 2000. The Village Electric Load Calculator is used to estimate both the 1996 and the 2001 seasonal load profiles, given the facilities that were available in Selawik at those times. The inputs that were used in the Electric Load Calculator for each year are shown in Table 13. 
Table 13. Load Calculator Inputs for Selawik

\begin{tabular}{|r|c|c|}
\hline Village Characteristics & $\mathbf{1 9 9 6}$ & $\mathbf{2 0 0 1}$ \\
\hline Population & 665 & 772 \\
\hline \# of Small Businesses & 3 & 4 \\
\hline \# of Large Commercial Businesses & 2 & 2 \\
\hline \# of Community Buildings & 1 & 1 \\
\hline \# of Government Offices & 3 & 4 \\
\hline Median Household Income & Medium & Medium \\
\hline K-12 School & Medium & High \\
\hline Public Water System & Level II Low & Level I High \\
\hline Health Clinic & Local & Local \\
\hline Communications & Basic & Basic \\
\hline Other Loads & $3 \%$ & $5 \%$ \\
\hline
\end{tabular}

The estimated results are graphed in Figure 28 along with the actual energy consumption determined from utility records.

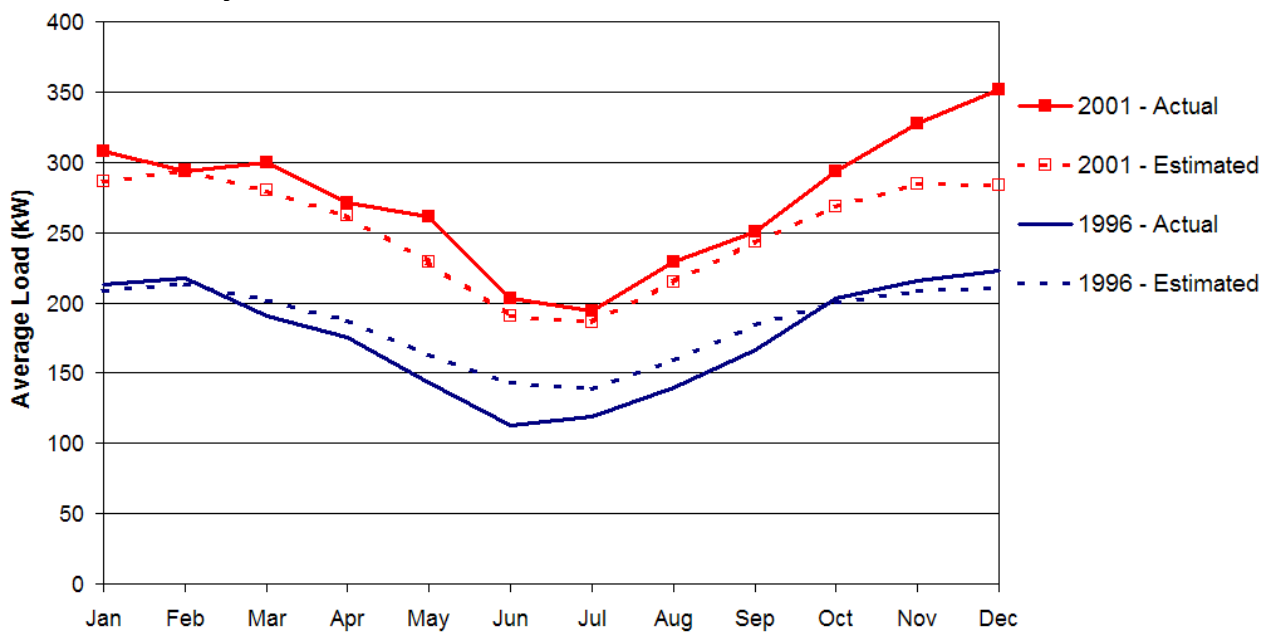

Figure 28. Load calculator model verification - village of Selawik.

The load calculator estimation method is typically within $8 \%$ of the actual electric usage for both years. The largest discrepancy occurs in December of 2001, when the actual usage was $24 \%$ more than the estimated usage.

\section{CONCLUSIONS}

Based on an analysis of electrical use in a number of rural Alaskan communities, this report presented a method to estimate the hourly electrical usage in a village -- one of the key pieces of information required to conduct any detailed power system analysis. Using the Alaska Village Electric Load Calculator method, one can build upon existing knowledge of expansion plans for different communities or estimate the energy usage of non-electrified communities by simply adding the different expected electric loads in a building block approach. Several examples were given, which result in estimations within an average of $10 \%$ accuracy. The Village Electric Load Calculator method of estimating village electric loads can serve as a useful guideline for power system designers and utility planners. 


\section{BIBLIOGRAPHY}

Alaska Village Electric Cooperative (AVEC). <http://www.avec.org $>$.

Alaska Energy Authority (AEA). <http://www.aidea.org/aea.htm>. Accessed Aug. 2003.

Coward, Mark. Hooper Bay City Office. Personal interview. May 2004.

Department of Community and Economic Development (DCED). Alaska Community Database. $<$ http://www.dced.state.ak.us/cbd/commdb/CF_BLOCK.htm>. Accessed June 2003 Aug 2004.

Davis, John. Bering Strait School District. E-mail correspondence. August 2003.

Energy Information Administration (EIA). "World Energy Use and Carbon Dioxide Emissions 1980-2001." <http://www.eia.doe.gov>. May 2004.

Maniilaq Association. <http://maniilaq.org $>$. Accessed August 2003.

Petrie, Brent. Manager of Special Projects and Key Accounts. Alaska Village Electric Cooperative. Personal correspondence. June 2003 - Aug 2004.

Rural Alaska Sanitation Coalition. $<$ http://www.anhb.org/sub/rasc $>$. Accessed August 2003.

Rural Alaska Project Identification and Delivery System (RAPIDS). Department of Community and Economic Development.

$<$ http://www.dced.state.ak.us/cbd/commdb/CF_BLOCK.htm>. Accessed June to Aug 2004.

Vallee, Randy. Assistant Manager of Operations and Maintenance. Alaska Village Electric Cooperative. E-mail correspondence. June 2003 and August 2004. 


\section{REPORT DOCUMENTATION PAGE}

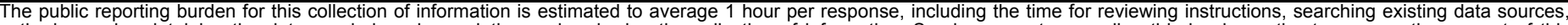

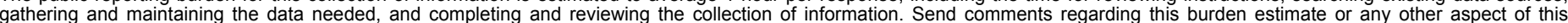

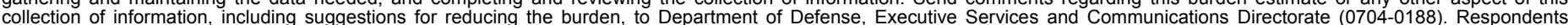

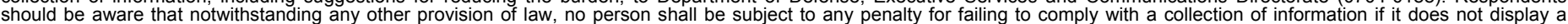

should be aware that notwithstandin

PLEASE DO NOT RETURN YOUR FORM TO THE ABOVE ORGANIZATION.

\begin{tabular}{l|l|l|}
\hline 1. REPORT DATE (DD-MM-YYYY) & 2. REPORT TYPE & 3. DATES COVERED (FrOm - TO)
\end{tabular}

October 2004

Technical Report

4. TITLE AND SUBTITLE

The Alaska Village Electric Load Calculator

5a. CONTRACT NUMBER

DE-AC36-99-G010337

5b. GRANT NUMBER

5c. PROGRAM ELEMENT NUMBER

6. AUTHOR(S)

M. Devine; E.I. Baring-Gould

5d. PROJECT NUMBER

NREL/TP-500-36824

5e. TASK NUMBER

WER4.6002

5f. WORK UNIT NUMBER
7. PERFORMING ORGANIZATION NAME(S) AND ADDRESS(ES)

National Renewable Energy Laboratory

1617 Cole Blvd.

Golden, CO 80401-3393
8. PERFORMING ORGANIZATION REPORT NUMBER

NREL/TP-500-36824

9. SPONSORING/MONITORING AGENCY NAME(S) AND ADDRESS(ES)

10. SPONSOR/MONITOR'S ACRONYM(S) NREL

11. SPONSORING/MONITORING AGENCY REPORT NUMBER

12. DISTRIBUTION AVAILABILITY STATEMENT

National Technical Information Service

U.S. Department of Commerce

5285 Port Royal Road

Springfield, VA 22161

13. SUPPLEMENTARY NOTES

14. ABSTRACT (Maximum 200 Words)

As part of designing a village electric power system, the present and future electric loads must be defined, including both seasonal and daily usage patterns. However, in many cases, detailed electric load information is not readily available. NREL developed the Alaska Village Electric Load Calculator to help estimate the electricity requirements in a village given basic information about the types of facilities located within the community. The purpose of this report is to explain how the load calculator was developed and to provide instructions on its use so that organizations can then use this model to calculate expected electrical energy usage.

15. SUBJECT TERMS

wind energy; distributed energy; Alaska; load calculator; village electric power system;

\begin{tabular}{|c|c|c|}
\hline $\begin{array}{l}\text { a. REPORT } \\
\text { Unclassified }\end{array}$ & $\begin{array}{l}\text { b. ABSTRACT } \\
\text { Unclassified }\end{array}$ & $\begin{array}{l}\text { c. THIS PAGE } \\
\text { Unclassified }\end{array}$ \\
\hline
\end{tabular}

\begin{tabular}{l|l|} 
17. LIMITATION \\
OF ABSTRACT \\
UL
\end{tabular}

19a. NAME OF RESPONSIBLE PERSON

19b. TELEPONE NUMBER (Include area code) 